Evaluation of Turkish language teaching for foreigners course programs of general directorate of lifelong learning in terms of various variables /T. Aytan; O. Uzun; Y. Günaydın ( (pp. 70-99)

\title{
5-Hayat boyu öğrenme yabancılara Türkçe öğretim kurs programlarının çeşitli değişkenler açısından değerlendirilmesi
}

Talat AYTAN 1

Oğuzhan UZUN²

Yusuf GÜNAYDIN3

\begin{abstract}
APA: Aytan, T.; Uzun, O.; Günaydın, Y. (2020). Hayat boyu öğrenme yabancılara Türkçe öğretim kurs programlarının çeşitli değişkenler açısından değerlendirilmesi. RumeliDE Dil ve Edebiyat Araştırmaları Dergisi, (21), 70-99. DOI: 10.29000/rumelide.835499.
\end{abstract}

\section{$\ddot{O} \mathbf{z}$}

Yabancılara Türkçe öğretimi, dil becerilerinin öğretiminin yanında hedef dilin kültürüne ait ögelerin aktarımı açısından oldukça önemli bir alandır. Bu alanda planlı ve programlı hareket edilerek öğretim faaliyetlerinin gerçekleştirilmesi gerekmektedir. Millî Ĕ̆itim Bakanlı̆̆ı bünyesinde hizmet veren Hayat Boyu Öğrenme Genel Müdürlüğü tarafından bu anlayışla Türkçenin yabancı dil olarak öğretiminde Diller İçin Avrupa Ortak Çerçeve Metni temel alınarak Yabancılara Türkçe Öğretimi Kurs Programları hazırlanmıştır. İlgili programda dört temel dil becerisinin yanında dil bilgisi ile birlikte Türk kültür ögelerini çeşitli etkinliklerle yabancı dil öğrenicilerine öğretmek amacı güdülmektedir. $\mathrm{Bu}$ nedenle çalışmada ilgili programların dil becerileri ve kültür aktarımının ele alınış biçimleri incelenerek elde edilen verilerin sunulması amaçlanmıştır. Çalışmada doküman analizi kullanılmıştır. Doküman analizi sonucunda ortaya çıkan veriler, çalışmanın bulgular kısmında sunulmuştur. Araştırma problemleri doğrultusunda ortaya çıkan bulgulara göre 1, 2 ve 3 . seviyeye ait kurs programlarında yer alan konu başlıkları ve kazanımlar içerisinde konuşma ve dil bilgisi becerilerine ağırlık verildiği görülmektedir. Bununla birlikte dinleme becerisine daha az yer verilmiştir. Kültür aktarımı açısından incelendiğinde ise Türk kültürünü yansıtma gücü bulunan kazanımlar tespit edilmiş ve çalışmanın bulgular kısmında sunulmuştur.

Anahtar kelimeler: Yabancılara Türkçe öğretimi, dil becerileri, kültür aktarımı

\section{Evaluation of Turkish language teaching for foreigners course programs of general directorate of lifelong learning in terms of various variables}

\begin{abstract}
Teaching Turkish to foreigners is a very important field in terms of transferring the elements of the culture of the target language as well as teaching language skills. It is necessary to carry out educational activities in this field by acting in a planned and programmed manner. With this understanding, the General Directorate of Lifelong Learning, serving under the Ministry of National Education, prepared Turkish Teaching for Foreigners Course Programs based on the Common
\end{abstract}

\footnotetext{
$1 \quad$ Doç. Dr., Yıldız Teknik Üniversitesi, Eğitim Fakültesi, Türkçe ve Sosyal Bilimler Eğitimi Bölümü, Türkçe Eğitimi ABD (İstanbul, Türkiye), talataytan@gmail.com, ORCID ID: oooo-0o01-9778-8970 [Araştırma makalesi, Makale kayıt tarihi: 27.09.2020-kabul tarihi: 20.12.2020; DOI: 10.29000/rumelide.835499]

2 Doktora Öğrencisi, Yıldız Teknik Üniversitesi, Sosyal Bilimler Enstitiüsü, Türkçe Eğitimi ABD (İstanbul, Türkiye), oguzhan.uzunn1993@gmail.com, ORCID: 0000-0003-4700-8360

3 Öğr. Gör., Ankara Yıldırım Beyazıt Üniversitesi, Rektörlük Merkezi (Ankara, Türkiye), yusuf.gunaydin@hotmail.com, ORCID ID: 0000-0002-0638-5621
}

Adres

İstanbul Medeniyet Üniversitesi, Eğitim Bilimleri Fakültesi, Türkçe ve Sosyal Bilimler Eğitimi Bölümü, Türkçe Eğitimi ABD Cevizli Kampüsü, Kartal-İstanbul/TÜRKIYE e-posta: editor@rumelide.com
Address

Istanbul Medeniyet University, Faculty of Education Sciences,

Turkish and Social Scinces Education, Turkish Language Teaching

Education, Cevizli Campus, Kartal-İstanbul /TURKEY

e-mail: editor@rumelide.com 


\begin{abstract}
European Framework of Reference for Languages in teaching Turkish as a foreign language. In the related program, it is aimed to teach Turkish cultural elements to foreign language learners with various activities along with four basic language skills. For this reason, it is aimed to present the data obtained by examining the language skills and the handling of cultural transfer elements of the related programs. Document analysis was used in the study. The data resulting from the document analysis are presented in the findings section of the study. According to the findings of the research problems, it is seen that speaking and grammar skills are emphasized among the topics and acquisitions in the course programs of the 1st, 2nd and 3rd levels. However, less attention has been paid to listening skill. When analyzed in terms of the transfer of cultural elements, gains that reflect Turkish culture were determined and presented in the findings section of the study.
\end{abstract}

Keywords: Teaching Turkish to foreigners, language skills, cultural transfer

\title{
Giriş
}

Dünyanın var oluşundan bugüne kadar kullanılmaya devam edilen dil, "insanlar arası bir anlaşma sistemidir" (Dilaçar, 1968: 28). Bu anlaşma sistemi birey-birey ve birey- toplum ilişkilerinde oldukça önemlidir. Söz konusu ilişki sürecinde, bireyin kendini ifade edebilmesi ve iletişim hâlinde olduğu diğer bireyleri anlayabilmesi dili kullanabilme becerisi sayesinde gerçekleşmektedir. Bu beceri insanları diğer canlılardan ayıran en temel özelliklerden biridir.

Alan yazında dil üzerine yapılmış birçok tanım bulunmaktadır. Söz konusu tanımlar içerisinde kapsamı en geniş olan ve günümüzde de geçerliliğini koruyan tanımlardan biri Ergin (2000:3) tarafından yapılmıştır. Ona göre dil, "İnsanlar arasında anlaşmayı sağlayan doğal bir araç, kendine özel kanunları olan ve bu kanunlar etrafında gelişen canlı bir varlık, temeli bilinmeyen zamanlarda atılmış gizli bir antlaşmalar sistemi, seslerden örülmüş sosyal bir kurum”dur. Söz konusu tanım dilin her yönüyle bir sistem olduğunu ve bu sistemin günümüzde de işlevlerini yerine getirmeye devam ettiğini göstermektedir. Banguoğlu (1986:9) ise dilin "insanların isteklerini anlatmak için kullandıkları sesli işaretler sistemi” olduğunu dile getirir. Bu noktadan hareketle dilin sistematik bir yapıya sahip olduğu ve insanın kendini ifade etmede en temel beceri olarak öne çıtı̆̆ı söylenebilir.

Dil, "dinleme, konuşma, okuma ve yazma" gibi alt becerilere sahip bir sistemdir. Sağlıklı bir iletişim başta olmak üzere eğitim ve iş gibi hayatın birçok alanında söz konusu dil becerileri aktif olarak kullanılmaktadır. Bireyin ana dilinin yanında hedef olarak belirlediği yabancı dil öğreniminde de dil becerilerinin önemi ortaya çıkmaktadır. Hedef dilin konuşucuları ile sağlıklı bir iletişim kurabilmek, o dilde eğitim almak ve bireyin kendini çeşitli alanlarda ifade edebilmesi için söz konusu dil becerilerine hâkim olması gerekmektedir.

Ana dil eğitiminde dil becerileri anlama ve anlatma olmak üzere iki ana başlık altında ele alınmaktadır. Anlama becerileri altında okuma ve dinleme yer alırken anlatma becerileri başlığı altında ise konuşma ve yazma becerilerine yer verilmektedir. Türkçe Dersi Öğretim Programı (2006) `nda dil bilgisi becerisine ayrı bir başlık açlırken son değişikliklerle birlikte güncelliğini koruyarak kullanılmaya devam edilen Türkçe Dersi Öğretim Programı (2019) `nda ise dil bilgisi becerisine ayrı bir başlık açılmadan okuma ve yazma becerileri ile birlikte verilmektedir.

Yabancı dil öğretimi alanında Diller İçin Avrupa Ortak Başvuru Metni (2001) `nde dil bilgisi becerisinin diğer dil becerileri içerisinde verilmesi öngörülmektedir. Bununla beraber dört temel dil

Adres

İstanbul Medeniyet Üniversitesi, Eğitim Bilimleri Fakültesi, Türkce ve Sosyal Bilimler Eğitimi Bölümü, Türkçe Eğitimi ABD Cevizli Kampüsü, Kartal-İstanbul/TÜRKIYE e-posta: editor@rumelide.com
Address

Istanbul Medeniyet University, Faculty of Education Sciences,

Turkish and Social Scinces Education, Turkish Language Teaching

Education, Cevizli Campus, Kartal-İstanbul /TURKEY

e-mail: editor@rumelide.com 
Evaluation of Turkish language teaching for foreigners course programs of general directorate of lifelong learning in terms of various variables /T. Aytan; O. Uzun; Y. Günaydın ( (pp. 70-99)

becerisinin geliştirilmesinde yine dil bilgisine ihtiyaç duyulmaktadır. Nitekim Hengirmen (1993:76), dil vücutsa dil bilgisinin bu vücudun iskeleti olduğunu belirtmiştir.

Ana dili eğitimi için hazırlanan programların dışında Türkiye Maarif Vakfı tarafından hazırlanan Yabancı Dil Olarak Türkçe Öğretimi Programı(2019)`nda dil bilgisi konularının öğretiminin belli becerileri destekleyecek şekilde yapılandırılması gerektiğinden bahsetmektedir. Bununla birlikte, yazılı ve sözlü anlatıma katkı sunmayan, sadece ezbere dayalı bilgiler içeren dil bilgisi konularının öğretilmemesi gerektiği belirtilmektedir. Konularda, Türkçenin yapısına uygun yapılandırma, aşamalılık ve ilişkisellik ön plana çıkmalıdır. Ayrıca dil bilgisi konuları dilin iletişimsel yönünü de desteklemelidir.

Programda yer alan dil becerilerinin belirli temalarla ilişkilendirilmiş kazanımlar aracıllğıyla yabancı dil öğrenicilerinde, kalıcı davranış hâline getirilmesi, ilgili programların temel amaçlarından biridir. $\mathrm{Bu}$ sebeple becerilere uygun temalar seçmek ve bu temaları ilgili kazanımlarla ilişkilendirerek programı hazır hâle getirmek oldukça önemlidir. Dil öğretiminde bireye o dil ile ilgili ne verilmek isteniyorsa programdaki temalar da ona göre belirlenir (CEFR,2001).

Araştırmaya konu olan, Hayat Boyu Öğrenme Genel Müdürlüğü tarafından hazırlanan Yabancılara Türkçe Öğretimi Kurs Programı; alfabe öğretimi konusuyla temelden başlayıp sayılar ve zaman, meslekler, günlük hayat ve etkinlikler gibi konulara yer vermektedir. Bununla birlikte yabancılara Türkçe öğretimi alanında Türkiye Maarif Vakfı tarafından hazırlanan Yabancı Dil Olarak Türkçe Öğretimi Programı (2019)'nda da temaların dil öğrenicilerinin seviyelerine uygun bir şekilde belirlenerek her temanın içeriğinin temayla ilgili kazanım, söz varlığı, iletişimsel işlevler ve işlevlere uygun dil yapılarıyla düzenlendiği bildirilmektedir. Söz konusu düzenleme ile dili kullanma alanlarından faydalanıldığı dile getirilmektedir. Bu noktada tema ve ilgili konuların günlük hayatla ilişkili olması, öğrenicilerin bilişsel hazırbulunuşluklarına uygun olarak kolaydan zora doğru hazırlanması oldukça önemlidir.

Dilin iletişimin yanı sıra mühim bir vazife üstlendiği alanlardan biri de "kültür aktarımı"dır. Kültür, kelime kökeni itibarıla "colere" (Latince) kelimesinden gelerek "culture" biçimiyle "ekin ekmek, işlemek" anlamı kazanıp genişleyerek "toplumların birikimli uygarlığı” hâline gelmiştir (Güvenç, 1974:95). Toplumun yaşayış tarzından sanatsal faaliyetlerine kadar içerisinde birçok bileşeni barındırmaktadır. Gökalp (1975: 27), kültürü "hars" kavramılla isimlendirerek "Bir milletin dinî, ahlakî, hukukî, muakalevî, bedî̂, lisanî, iktisadî, fennî hayatların ahenkli mecmuasıdır" şeklinde tanımlamıştır. Söz konusu tanımda, kültürün çok boyutlu olduğu ve insan hayatının her alanında varlığını koruduğu görülmektedir.

Kültür ile ilgili en kapsamlı tanımlardan biri Burnett Tylor tarafından yapılmıştır (Güvenç, 1974): "Toplumun üyesi olarak insan türünün öğrendiği, edindiği bilgi, sanat, beceri, yetenek ve alışkanlıkları içine alan karmaşık bir bütündür”. Gökalp (1975 :27) ‘in tanımıyla benzerlik gösteren bu tanımda da görüldüğü üzere, kültür kavramı, insan hayatını ilgilendiren alanların bir araya gelerek oluşturduğu bir bütün olarak görülmektedir. Bununla birlikte Güvenç (1974) bu alanları açıklayarak kültürü "bilim alanında medeniyet, beşerî alanda eğitim sürecinin bir sonucu, estetik alanda güzel sanatlar, teknolojik ve biyolojik alanda üreme, tarım, yetiştirme" şeklinde ifade etmiştir.

Söz konusu alanın kapsamı geniş olduğu için kültür ile ilgili yapılacak tanımların da yetersiz olduğu dile getirilmektedir. Meriç (1986:9) bu durumu şu sözlerle açıklamaktadır “Dünyada kültürden daha

\footnotetext{
Adres $\mid$ Address

İstanbul Medeniyet Üniversitesi, Eğitim Bilimleri Fakültesi, Türkçe İstanbul Medeniyet University, Faculty of Education Sciences, ve Sosyal Bilimler Eğitimi Bölümü, Türkçe Eğitimi ABD Cevizli Turkish and Social Scinces Education, Turkish Language Teaching Kampüsü, Kartal-İstanbul/TÜRKIYE $\quad$ Education, Cevizli Campus, Kartal-İstanbul /TURKEY e-posta: editor@rumelide.com 1 e-mail: editor@rumelide.com
} 
kaypak bir mefhum tanımıyorum. Tahlil edemezsiniz çünkü unsurları sonsuz. Tasvir edemezsiniz çünkü bir yerde durmaz. Manasını kelimelerle belirtmeye kalkıştınız mı, elinizle havayı tutmuş gibi olursunuz. Bakarsınız ki her yerde hava var ama avuçlarınız bomboş”.

Alan yazında çok çeşitli şekillerde tanımlanmaya çalışılan kültürün dil ile güçlü bir bağlantısı bulunmaktadır. Hedef dilin konuşulduğu coğrafyadaki kültürel ögelerin varlığının korunabilmesi ve gelecek nesillere aktarımının sağlanabilmesi dilin varlığı sayesinde gerçekleşmektedir. Bu noktada dil ve kültür arasındaki ilişkinin önemi ortaya çlkmaktadır. Kaplan (2010), kültürü olmayan bir toplumu kaynağı tükenmek üzere olan bir nehre benzetirken dili olmayan kültürü ise temelsiz bir binaya benzetmektedir. Bu benzetim dil ve kültürün birbirinden ayrılmaz parçalar olduğu durumunu daha iyi açıklamaktadır. Dil, bu noktada kültürü yansıtan bir araç konumundadır, aynı zamanda kültüre kimlik kazandırmaktadır. "Bu nedenle dili öğrenmek o dilin taşıyıcısı olduğu kültürü öğrenmektir" (Kramsch:1993).

"Humboldt`a göre dil ve kültür karşllklı olarak gelişen bir bütündür" (Topkaya, 2016), birbirini beslemektedir. Demirkan ve Başkan (2016:38) dili toplumdan soyutlayarak düşünmenin faydacı bir yaklaşım olmadığını, bu nedenle dört dil becerisinin yanına kültürün beşinci bir beceri olarak eklenmesi gerektiğini dile getirir. Dil öğretimi aynı zamanda dilin kültürel boyutunun sistemli bir şekilde aktarılmasını zorunlu kılar.

Türkçe, dünya üzerinde varlığını sürdüren, kültürel birikim bakımından en köklü en geniş coğrafyada konuşulan dillerden biridir. Türklerin zaman içerisinde farklı coğrafyalarda farklı kavimlerle ilişki içerisinde olması Türkçenin bugünkü konumunu belirlemiştir. Tarihin erken dönemlerinde Hunlarla birlikte başlayan serüven Göktürkler ve Uygurlar ile devam etmiş; İslam ile tanışmanın ardından batıya ve güneye yayılarak farklı kavimlerle etkileşim içerisinde olunmuştur. Bu durum, diğer alanlarda olduğu gibi dil ve kültürde etkileşimini de sağlamıştır. Karahanlılar döneminde üretilen eserler bu durumu en iyi şekilde özetlemektedir.

Bir sözlük niteliği taşıyan Divan-ı Lügati `t Türk, bu özelliğinin dışında Türk folkloru, Türk yerleşim bölgeleri haritası, atasözü, şiir gibi sosyal hayatın yansımaları olan unsurları da bünyesinde barındırmaktadır. İçerisinde 7500 Türkçe sözcük ve bu sözcüklerin Arapça karşllıklarının yer aldığı söz konusu eser Kaşgarlı Mahmut tarafindan yazılarak Abbasi halifesine sunulmuş ve kabul görmüştür.

Divan-ı Lügati `t Türk dışında Yabancı dil olarak Türkçe öğretimi alanında verilen diğer eserlerden bazıları şunlardır: Codex Cumanicus, Et- Tuhfetü`z Zekiye fi` Lügat `i-t Türkiye, Kitabû`l İdrak liLisâni`l Etrak, El Kavaninü`l Külliye li Zati`l Lügati`t Türkiyye, Muhakemetü`l Lügateyn (Bayraktar, 2003). Söz konusu eserler, sözlük tarzında yazılarak dönemin söz varlığını ve kültür unsurlarını Türkçe öğrenmek isteyen yabancılara aktarmıştır.

Günümüzde Türkçeye olan talep artarak devam etmektedir. Türkiye’ye her yıl milyonlarca yabancı gelmektedir. TÜIK (2019) tarafından yayınlanan son verilere göre 2019 yılında Türkiye'ye gelen yabancı kişi sayısı 45058286 olarak belirlenmiştir. Siyasi nedenlerle yaşanan göç dalgaları da Türkiye'ye yabancı kişilerin girişini artırmaktadır. Afganistan, Irak, Suriye gibi ülkelerden Türkiye'ye yapılan geçişler bunun en canlı örneğidir. Söz konusu durumdan ötürü Türkiye'de kayıtlı mülteci sayısı 3,1 milyonu aşmıştır (“Syria Regional Refugee Response”, 2018). Bu durum, Türkiye'ye ve Türkçeye olan talebin hâlihazırda canlılı̆̆ını korumasını da sağlamaktadır.

\footnotetext{
Adres $\mid$ Address

İstanbul Medeniyet Üniversitesi, Eğitim Bilimleri Fakültesi, Türkçe İstanbul Medeniyet University, Faculty of Education Sciences, ve Sosyal Bilimler Eğitimi Bölümü, Türkçe Eğitimi ABD Cevizli Turkish and Social Scinces Education, Turkish Language Teaching Kampüsü, Kartal-İstanbul/TÜRKIYE $\quad$ Education, Cevizli Campus, Kartal-İstanbul /TURKEY e-posta: editor@rumelide.com 1 e-mail: editor@rumelide.com
} 
Evaluation of Turkish language teaching for foreigners course programs of general directorate of lifelong learning in terms of various variables /T. Aytan; O. Uzun; Y. Günaydın ( (pp. 70-99)

Türkçeye olan bu talep, Türkiye'de üniversiteler bünyesinde kurulan Türkçe Öğretim Merkezleri (TÖMER), Yunus Emre Enstitüsü ve Millî Eğitim Bakanlı̆̆ına bağlı kurumlarla karşlanmaya çalışılmaktadır. Üniversite bünyesinde kurulan ve faaliyete geçen ilk TÖMER 1984 yllında Ankara Üniversitesi dâhilinde açılmıştır. Bununla birlikte yıllar içerisinde Ege Üniversitesi, Gazi Üniversitesi, İstanbul Üniversitesi gibi üniversiteler başta olmak üzere birçok yerde söz konusu kurumlar açlmıştır ve bu kurumlar hâlihazırda Türkçeye olan talebi karşlamaya devam etmektedir. Bununla beraber Yunus Emre Enstitüsü ise yurt dışında Türkçeyi yabancı dil olarak öğrenmek isteyen bireyler ile yurt dışına çeşitli nedenlerle giden Türk soylulara Türkçe eğitimi vermeyi amaçlamaktadır.

Türkiye'deki yabancılara Türkçe öğretim faaliyetleri, Diller İçin Avrupa Ortak Başvuru Metni (2001)`ni temel almaktadır. Söz konusu temelin Türkçe öğretim setlerine yansımalarında ise farklılıklar görülmektedir. Bir öğretim setinde konuşma becerisine ağırlık verilirken başka bir öğretim setinde dil bilgisi becerisine ağırlık verilebilmektedir. Şimşek ve Aktaş (2016) tarafından gerçekleştirilen çalışmada, İstanbul Yabancılar için Türkçe Öğretim Seti ve Yunus Emre Enstitüsü Türkçe Öğretim Seti B2 düzeyi ders kitapları karşlaştırılarak incelenmiş ve dinleme becerisi etkinliklerinin geri planda bırakıldığı gözlemlenmiştir. Bununla beraber okuma becerisine yönelik etkinliklerin ön plana çıktığı belirtilmiştir. Kültür aktarımı konusuna da Yunus Emre Enstitüsü Türkçe Öğretim Seti’nde daha fazla önem verildiği belirtilmiştir. Söz konusu uygulama farklılıkları, ortak bir program ve bu program doğrultusunda hazırlanan yabancılara Türkçe öğretim setleri olmayışından kaynaklanmaktadır.

TÖMER ve Yunus Emre Enstitüsünün yabancılara Türkçe öğretimi faaliyetleri dışında Millî Eğitim Bakanlığı Hayat Boyu Öğrenme Genel Müdürlüğü bünyesindeki yabancı dil olarak Türkçe öğretim faaliyetleri, Türkiye'de yaşayan mültecilerin, yaş ayırt etmeksizin, tamamına hitap eden dil öğretim faaliyetlerini yerine getirmektedir. Özellikle Suriye'de yaşanan siyasi krizden ötürü yerlerini terk ederek Türkiye'ye göç eden kitlede çocuk oranının fazla olması ve Türkiye'de yaşayan mültecilerin yaşamlarını devam ettirebilmeleri için Türkçe öğrenmeye ihtiyaç duymaları söz konusu dil öğretim faaliyetlerinin küçük yaş gruplarına yönelik olarak gerçekleştirilmesini zorunlu kılmaktadır. Bu sebeple 2016 yllında Hayat Boyu Öğrenme Genel Müdürlüğü bünyesinde 6-12 yaş (1, 2 ve 3. Seviye Kurs Programı), 13-17 yaş (1, 2 ve 3. Seviye Kurs Programı) ve Harmanlanmış Model (A1, A2, B1 Kurs Programı) gibi üç farklı program hazırlanmıştır. Bu çalışmada Hayat Boyu Öğrenme Genel Müdürlüğü tarafindan hazırlanan Yabancılara Türkçe Öğretimi (13-17 Yaş) 1, 2 ve 3. Seviye Kurs Programları çeşitli değişkenler açısından ele alınarak incelenmiştir.

\section{Yabancılara Türkçe öğretimi (13-17 yaş) 1, 2 ve 3. seviye kurs programları}

Hayat Boyu Öğrenme Genel Müdürlüğü tarafından hazırlanan söz konusu program, 13-17 yaş seviyesini dikkate alarak 3 farklı seviyede hazırlanmıştır. Seviyeler 1,2 ve 3 şeklinde derecelendirilmiştir. Söz konusu seviyeler birbirinin devamı niteliğindedir.

Her üç seviye programın giriş kısmında "Programın Dayanağı" başlı̆̆ı altında program oluşturulurken başvurulan temel dayanaklar belirtilmiştir. Bunlar:

- 1739 Sayılı Millî Eğitim Temel Kanunu

- 652 Sayılı Millî Eğitim Bakanlığının Teşkilat ve Görevleri Hakkında KHK

- Talim ve Terbiye Kurulu Başkanlığının 05.08.2015 tarih ve 71 sayılı kararıyla kabul edilen İlköğretim Türkçe Dersi Öğretim Programı (Değişiklik 07.03.2016/12)

\footnotetext{
Adres $\mid$ Address

İstanbul Medeniyet Üniversitesi, Eğitim Bilimleri Fakültesi, Türkçe İstanbul Medeniyet University, Faculty of Education Sciences, ve Sosyal Bilimler Eğitimi Bölümü, Türkçe Eğitimi ABD Cevizli $\quad$ Turkish and Social Scinces Education, Turkish Language Teaching Kampüsü, Kartal-İstanbul/TÜRKIYE $\quad$ Education, Cevizli Campus, Kartal-İstanbul /TURKEY e-posta: editor@rumelide.com 1 e-mail: editor@rumelide.com
} 
- Talim ve Terbiye Kurulu Başkanlığının 20.04.2016 tarih ve 19 sayılı kararıyla kabul edilen Yaygın Eğitim Kursları Çerçeve Programı

- Talim ve Terbiye Kurulu Başkanlığının 15.08.2016 tarih ve 79031618-235-E.8667808 sayılı yazısıdır.

Hayat Boyu Öğrenme Genel Müdürlüğü tarafından yabancılara Türkçe öğretmek amacıyla hazırlanan bu programda 12 yaşını tamamlamış olmak ve 18 yaşından gün almamış olmak giriş şartı olarak getirilmiştir. Programın 2. seviyesinde bu şartların yanında "1. Seviye Kurs Programını başarmış olmak", "Bu programa katılmayanlar için yapılacak seviye tespit sınavında 1. seviye düzeyinde Türkçe bilgisine sahip olduğunu kanıtlamak" şartları getirilmiştir. Programın 3. seviyesinde ise "2. Seviye Kurs Programını başarmış olmak”, "2. Seviye Kurs Programına katılmayanlar için yapılacak olan seviye tespit sınavında söz konusu seviye düzeyinde Türkçe bilgisine sahip olduğunu kanıtlamak” şartı yer almaktadır. Programların farklı seviyelerinde yer alan tüm bu şartlar söz konusu programların birbirinin devamı niteliğinde hazırlandığının göstergesidir. Programın belirlenen seviyesini sağlıklı bir şekilde tamamlamadan bir başka seviyeye geçmek mümkün değildir.

Programı yürütecek olanların kimler olacağı ve bu kişilerin özellikleri "Eğitimcilerin Niteliği” başlı̆̆ı altında maddelendirilmiştir. Buna göre; Millî Eğitim Bakanlığında görevli sınıf öğretmenleri, Türkçe öğretmenleri ve Türk dili ve edebiyatı öğretmenleri ile Millî Eğitim Bakanlığı haricinden vazifelendirileceklerden "sınıf öğretmenliği, üstün zekâlllar öğretmenliği, Türkçe öğretmenliği, Türk dili ve edebiyatı öğretmenliğginden mezun olanlar, Türk dili ve edebiyatı, çağdaş Türk lehçeleri ve edebiyatları, Türk halkbilimi bölümlerinden mezun ve öğretmenlik formasyon belgesine sahip olanlar, yan dalı Türkçe olanlar ve Türkçe öğretimi sertifikasına sahip olduğunu belgelendirenler arasından görevlendirilir.

İlk ve ortaöğretim kademelerine yönelik hazırlanan her ders programında olduğu gibi bu programda da "Programın Amaçları" başlığı altında ilgili amaçlar sıralanmıştır. Söz konusu amaçlar 1, 2 ve 3. seviyelerde farklılık taşımaktadır. İlgili amaçlar Tablo. 1'e sıralanmıştır.

Yabancılara türkçe öğretimi 13-17 yaş 1, 2 ve 3. seviye programlarının amaçları

1.Seviye

1.Türk dilinin alfabesini öğrenmeleri; ses bilgisi, telaffuz ve yazma yeterliliği kazanmaları,

2.Karşısındaki ile selamlaşmaları ve kendilerini tanitmaları,

3.Okulu, evi ve çevresi ile ilgili bilgi vermeleri,

4. 1' den 100'e kadar sayma ve sira sayılarını saymaları,

5.Saati sormaları ve söylemeleri. Gün, ay, yll, mevsim, gibi zaman ile ilgili kelime ve ifadeleri kullanmaları,

6.Vücudun organlarını ve kişisel bakım eşyalarının isimlerini bilmeleri,

2.Seviye

1.Ürünlerin isimlerini bilmeleri ve fiyatlarını sorarak alışveriş yapmaları,

2.Sağlık ve spor ile ilgili kelimeleri bilmeleri,

3.Sevdiği ve yaptığı sporlar hakkında konuşmaları,

4.Şu anda yaptığı ve yapmadığı işleri söylemeleri,

5.Yer yön tarifi yapabilmeleri ve anlamaları,

6.Dilekçe form veya mektuplara adreslerini yazabilmeleri,

\section{Seviye}

1. Kendini ayrıntılı olarak tanitmaları,

2. Gelecekle ilgili beklentilerini, hayallerini ve planlarmı söylemeleri,

3. TV ve radyodaki kısa anons ve haberlerin önemli noktalarını anlamaları,

4. Kültürel etkinliklerle ilgili davetleri anlamaları ve uyulması gereken kuralları söyleyebilmeleri,

5. Aldığı eğitimi, okulunu, bölümünü, okul çalışanlarını ve okuldaki günlük etkinliklerini söyleyebilmeleri,

6. Mesleklerin isimlerini, mesleklere ilişkin fikirlerini söylemeleri ve bir iş başvuru
Adres İstanbul Medeniyet Üniversitesi, Eğitim Bilimleri Fakültesi, Türkçe ve Sosyal Bilimler Eğitimi Bölümü, Türkçe Eğitimi ABD Cevizli Kampüsü, Kartal-İstanbul/TÜRKIYE e-posta: editor@rumelide.com 
Evaluation of Turkish language teaching for foreigners course programs of general directorate of lifelong learning in terms of various variables /T. Aytan; O. Uzun; Y. Günaydın ( (pp. 70-99)

7.Günlük temel ihtiyaçlardan olan yiyecek, içecek ve kıyafetlerin isimlerini söylemeleri ve yazmaları,

8.Çevresindeki eşyaların renklerini söylemeleri,

9.Başlıca meslekleri bilmeleri ve meslek sahiplerinin ne yaptıklarını açıklamaları,

10.Ürünlerin fiyatlarını sormaları,

11.Basit nezaket kalıplarını kullanmaları,

12.Okuduğu, dinlediği ve izlediğinden hareketle, söz varlığını zenginleştirerek dil zevki ve bilincine ulaşmaları; duygu, düşünce ve hayal dünyalarını geliştirmeleri,

13.Türkçe Okuma ve yazma sevgisi ile alışkanlığını kazanmaları amaçlanmaktadır.
7.Yapmaktan hoşlandığı veya hoşlanmadığı etkinliklerden bahsetmeleri,

8.Hobileri ve fobileriyle ilgili konuşabilmeleri,

9.Kabiliyetlerini ve alışkanlıklarını ifade etmeleri,

10.Zorunluluk bildiren durumları ifade edebilmeleri,

11.Hava durumuna ilişkin ifadeleri anlamaları,

12.Günlük hayatta kullanılan iletişim araçlarını tanımaları,

13. Resmî ve millî bayramlar, kutlamalar gibi özel günleri bilmeleri,

14.Özel günlerde kutlama
yapabilmeleri,

15.Tatil ve seyahate ilişkin temel kelimeleri kullanarak yaptıkları tatil planlamasını söylemeleri,

16.Okuduğu, dinlediği ve izlediğinden hareketle, söz varlığını zenginleştirerek dil zevki ve bilincine ulaşmaları; duygu, düşünce ve hayal dünyalarını geliştirmeleri,

17.Türkçe Okuma ve yazma sevgisi ile alışkanlığını kazanmaları, amaçlanmaktadır. formunu doldurabilmeleri,

7. Niçin, neden, nasıl, ne zaman, ne kadar gibi soru kelimelerini doğru kullanmaları,

8. Geçmişteki olaylardan anı ve tecrübelerinden bahsedebilmeleri,

9. İnsan ilişkileri, toplum ve birey gibi konularda yapılan bir sohbeti ana hatları ile anlamaları,

10. Ulaşım ve ulaşım araçları ile ilgili kelimeleri doğru kullanarak bilet, yer ayırtma gibi işlemleri yapabilmeleri, uyarı tabelalarını anlamaları,

11. Yer yön tarifi yapabilmeleri ve anlamaları,

12. İzlediği sanat olayları ile ilgili duygularını ifade edebilmeleri amaçlanmaktadır.

Tablo.1 Yabancılara Türkçe Öğretimi 13-17 yaş 1, 2 ve 3. Seviye Programlarının Amaçları

Programın üç seviyesinde de farklı sayıda amaçlara yer verilmiştir. Söz konusu amaçlar bir sonraki seviyede aşamalı olarak ilerlemektedir. Birinci seviyede on üç amaç yer alırken ikinci seviyede on yedi, üçüncü seviyede ise on iki amaç yer almaktadır. Üç seviyede de farklı sayılarda yer verilen amaçlara bakıldığında basitten karmaşı̆̆a doğru bir yol izlendiği görülmektedir. Ayrıca programda yer verilen kazanımlar da bu amaçlar doğrultusunda hazırlanarak aralarında bir bağlantı kurulmuştur.

Amaçlar ve söz konusu amaçlara bağlı olarak hazırlanan kazanımlar oluşturulurken yabancı dil öğretiminde de dikkat edilmesi gereken bazı ilkeler göz önünde bulundurulmalıdır. Barın (2004: 2224) ve Demirel (2011: 29-32) söz konusu ilkeleri şu şekilde sıralamıştır: 
- $\quad$ Etkinlikler önceden planlanmalı

- Dört temel beceriyi bir bütün hâlinde geliştirmeli

- Basitten karmaşığa, somuttan soyuta doğru öğretilmeli

- Görsel ve işitsel araçlar kullanılmalı

- Gerekli durumlarda anadile başvurulmalı

- Bireysel farklılıklar dikkate alınmalı

- Verilen bilgi ve örnekler hayata uygun olmalı

- Bir seferde tek yapı gösterilmeli.

Programın uygulanmasıyla ilgili açıklamalara bakıldığında, yaygın eğitim merkezleri için düzenlendiği ve Diller İçin Avrupa Ortak Başvuru Metni (2001) göz önüne alınarak Türkçe öğrenmek isteyen yabancıların ihtiyaçlarını karşılayacak şekilde hazırlandı̆̆ı belirtilmektedir. Yabancılara Türkçe öğretimi konusunda hazırlanan program ve diğer materyallerin temel dayanaklarından birisi Diller İçin Avrupa Ortak Başvuru Metni (2001)'dir. Söz konusu programın bu metni temel alarak hazırlanması dil öğretiminin Avrupa standartlarında olması açısından gerekli görülmektedir.

Programın uygulayıcısı olan öğretmenlerin bu süreçte kendilerini sadece bilgi veren bir kaynak olarak görmelerinden ziyade, kurstaki öğrencilerin kendilerini keşfetme sürecini kolaylaştırıcı bir rehber olarak görmeleri önemlidir. Program genel bir çerçeve çizse de burada yer alan kazanımların öğrencilere aktarılması süreci tamamen öğretmenin bilgi ve becerisine bağlıdır. $\mathrm{Bu}$ nedenle öğretmenin rolü bu noktada oldukça önemlidir.

Programın uygulanmasıyla ilgili yer alan açıklamalardan biri de "Temaların Uygulanması" başlı̆̆ı altında yer almaktadır. Bu kısımda yukarıda yer alan dil öğretim ilkelerine uyularak temaların belirlendiği ve belirlenen temalara uygun kazanımların yerleştirildiği belirtilmektedir. Bunlar arasında "basitten karmaşığa, somuttan soyuta, bilinenden bilinmeyene, dört temel becerinin bir arada öğretilmesi, görsel ve işitsel araçlardan yararlanma, iletişimsel ve işlevsel dil eğitimi”ne özellikle değinilmiştir.

Dört temel dil becerisinin öğretilmesiyle ilgili olarak amaçlar ve kazanımlar verilirken beceriler için ayrı bir başlık açılmamıştır. Onun yerine, kazanımlarda yer alan sözel ipuçlarından hareketle hangi kazanımın hangi beceriyi aktif hâle getirdiği bilgisi verilmiştir. Buna göre, "anlar, bulur, okur, seçer, takip eder" gibi kazanım ifadeleri dinleme ve okuma becerilerine yönelikken "yazar, konuşur, ifade eder, açıklar, sorar" gibi kazanımlar ise üretime dönük olup konuşma ve yazma becerilerini harekete geçirdiği belirtilmiştir.

Programın süresi ve içeriği kısmında ise üç kur seviyesinin 168 saatlik uygulama süresi olduğu belirtilmektedir. Programda yer alan her konuya 24 saatlik bir süre ayrllarak toplamda 168 saat verilmiştir. Bununla beraber her kur seviyesinde yedi konu yer almaktadır. Haftalık ders saati, günlük 5 saati geçmemek üzere kursun verileceği eğitim merkezinin şartları da göz önünde bulundurularak kurs eğitim merkezi müdürü ve kurs zümre öğretmenleri tarafından kararlaştırılmaktadır.

1, 2 ve 3. seviye kur programında yer alan konular ve süreleri aşağıdaki tabloda yer almaktadır.

\begin{tabular}{|c|c|}
\hline Konular & Süre (Ders Saati) \\
\hline Alfabe Öğretimi & 24 \\
\hline Tanışma ve Arkadaşlık & 24 \\
\hline $\begin{array}{r}\text { Adres } \\
\text { İstanbul Medeniyet Üniversitesi, Eğitim Bilimleri Fakültesi, Türkce } \\
\text { ve Sosyal Bilimler Eğitimi Bölumü, Türkce Eğitimi ABD Cevizli } \\
\text { Kampüsü, Kartal-İstanbul/TÜRKiYE } \\
\text { e-posta: editor@rumelide.com }\end{array}$ & $\begin{array}{l}\text { Address } \\
\text { İstanbul Medeniyet University, Faculty of Education Sciences, } \\
\text { Turkish and Social Scinces Education, Turkish Language Teaching } \\
\text { Education, Cevizli Campus, Kartal-İstanbul /TURKEY } \\
\text { e-mail: editor@rumelide.com }\end{array}$ \\
\hline
\end{tabular}


Evaluation of Turkish language teaching for foreigners course programs of general directorate of lifelong learning in terms of various variables /T. Aytan; O. Uzun; Y. Günaydın ( (pp. 70-99)

$\begin{array}{ll}\text { Ailem ve Çevrem } & 24 \\ \text { Sayılar ve Zaman } & 24 \\ \text { Dış Görünüş ve Kişisel Bakım } & 24 \\ \text { Temel İhtiyaçlar } & 24 \\ \text { Meslekler } & 24 \\ \text { Toplam } & 168\end{array}$

Tablo. 2 Yabancılara Türkçe Öğretimi 1. Seviye Kurs Programı Konu ve Süre Dağılımı

\begin{tabular}{ll}
\hline Konular & Süre (Ders Saati) \\
\hline Giriş & 24 \\
Alışveriş & 24 \\
Sağlık ve Spor & 24 \\
Günlük Hayat ve Etkinlikler & 24 \\
Serbest Zaman Etkinlikleri & 24 \\
Hava Durumu ve İletişim & 24 \\
Kutlamalar ve Tatil & 24 \\
Toplam & 168
\end{tabular}

Tablo.3 Yabancılara Türkçe Öğretimi 2. Seviye Kurs Programı Konu ve Süre Dağılımı

\begin{tabular}{ll}
\hline Konular & Süre (Ders Saati) \\
\hline Giriş & 24 \\
Hayallerim ve Ben & 24 \\
Medya ve Kültür & 24 \\
Eğitim ve Çalışma Hayatı & 24 \\
Anılar- Geçmiş & 24 \\
Toplum ve Birey & 24 \\
Duygular ve Sanat & 24 \\
Toplam & 168
\end{tabular}

Tablo. 4 Yabancılara Türkçe Öğretimi 3. Seviye Kurs Programı Konu ve Süre Dağılımı

1. Seviye Kurs Programı'nda yer alan konuların daha temel kavramlara yönelik olduğu görülmektedir. Alfabe Öğretimi, Tanışma ve Arkadaşlık, Ailem ve Çevrem, Sayılar ve Zaman, Dış Görünüş ve Kişisel Bakım, Temel İhtiyaçlar, Meslekler gibi başlıklar altında öğrencilere hedef dilde kullanacakları temel sözcük ve cümle kalıplarının öğretilmesi hedeflenmektedir.

Programın 2. ve 3. seviyelerinde ise Giriş konusuyla kursa başlandığı görülmektedir. Söz konusu Giriş bölümünde bir önceki kurs kazanımlarının öğrencilere hatırlatılması ve varsa öğrenci eksikliklerini belirlemek amacıyla 10 saatlik bir bölüm ayrıldığı belirtilmektedir. Bununla beraber geriye kalan 14 saatlik sürede de öğrencilere verilmesi gereken on bir kazanım yer almaktadır.

2. Seviye Kurs Programı’nda, öğrencilerin günlük hayatta kullanacakları sözcük ve cümle kalıplarının öğretimine yönelik kazanımların varlığıyla birlikte tatil dönemi ve kutlamalarda kullanması gereken

\footnotetext{
\begin{tabular}{r|l} 
Adres & Address \\
İstanbul Medeniyet Üniversitesi, Eğitim Bilimleri Fakültesi, Türkçe & İstanbul Medeniyet University, Faculty of Education Sciences,
\end{tabular} ve Sosyal Bilimler Eğitimi Bölümü, Türkce Eğitimi ABD Cevizli Turkish and Social Scinces Education, Turkish Language Teaching Kampüsü, Kartal-İstanbul/TÜRKIYYE $\quad$ Education, Cevizli Campus, Kartal-İstanbul /TURKEY e-posta: editor@rumelide.com 1 e-mail: editor@rumelide.com
} 
sözcük ve cümle kalıplarının öğretimi için gerekli kazanımlar yer almaktadır. 3. Seviye Kurs Programında ise dilin basit kullanımından ziyade daha karmaşık yapılarının kullanımının öğretilmesi üzerine sıralanan konular ve kazanımlar yer almaktadır.

Programın son bölümünde ölçme ve değerlendirme ile ilgili esaslara yer verilmiştir. Buna göre kurs süresi boyunca edinilen kazanımların kurs bitiminde bütünüyle değerlendirileceği belirtilmektedir. Kişisel ve grupla yapılan etkinliklerin de değerlendirilmeye alınacağından bahsedilmektedir. $\mathrm{Bu}$ yönüyle ölçme değerlendirme faaliyetlerinin bütüncül bir bakış açısıyla gerçekleştirilmesi gerektiği söylenebilir. Diller İçin Avrupa Ortak Başvuru Metni (2001)'nde de öğrencilerin dil ile ilgili becerilerinin ölçülmesinde tek bir ölçme ve değerlendirme yöntemine bağlı kalınmadan bütüncül bakış açısıyla ölçme ve değerlendirme gerçekleştirilmesinin önemli olduğundan bahsedilmektedir. Ancak Hayat Boyu Öğrenme Genel Müdürlüğünün hazırlamış olduğu kurs programlarında öğrencilerin kursa hangi seviyeden başlayacaklarına yönelik bir seviye tespit sınavından bahsedilmemiştir. Bu noktada öğrencilerin seviyelerinin neye göre belirlendiği konusu belirsiz kalmaktadır.

\section{Alan yazındaki araştırmalar}

Alan yazında Hayat Boyu Öğrenme Genel Müdürlüğü tarafından hazırlanan Yabancılara Türkçe öğretimi programlarına yönelik herhangi bir inceleme çalışması bulunmamaktadır. Ancak, Diller İçin Avrupa Ortak Başvuru Metni (2001) temel alınarak hazırlanan materyallere ve bu yönde yapılan öğretim faaliyetlerine, bu faaliyetlere katılan öğretici ve öğrencilere yönelik inceleme çalışmaları bulunmaktadır. Söz konusu çalışmalar içerisinde dil-kültür ilişkisini ele alanlardan bazıları şunlardır:

İşçi (2012), Türkçenin yabancı dil olarak öğretiminde kullanılan ders kitaplarından biri olan "Yeni Hitit” ders kitabını kültür ve dört temel beceri açısından incelemiştir. Bu çalışmaya göre kültürel açıdan ele alınan 49 metinden 4 tanesi kültürler arası karşılaştırma yapmaya yönelik etkinlik bulundurmaktadır. Kültürel etkinliklerin sayısının artırılması yönünde öneri sunulmaktadır.

Kültürün temel yansıtıcılarından biri olan folkloru ele alan bir çalışma Özdemir (2013) tarafından gerçekleştirilmiştir. Söz konusu çalışmada, Türkçenin yabancı dil olarak öğretiminde öğrencilerin Türk kültürü konusunda aydınlatılmasının gerekliliğinden bahsedilmektedir. Bu sebeple çalışmada yabancılara Türkçe öğretiminde folklor çıktılarının görevsel kullanımıyla ilgili yaklaşım ortaya koyarak örnekler sunulmuştur.

Ökten ve Kavanoz (2014) "Yabancı Dil Olarak Türkçe Öğretimini Hedefleyen Ders Kitaplarında Kültür Aktarımı” isimli çalışmalarında, Türk kültürüne ait ögelerin kitaplarda kültürlerarası öğrenmeyi destekleme konusunda yetersiz kaldığını belirtmektedir. Ayrıca çalışmada dilbilgisi ve sözcük öğretiminin ön planda olduğu, bu sebeple kültürel etkileşimin geri planda kaldığı da not edilmektedir.

Elbir ve Aka (2015) tarafından gerçekleştirilen "Yabancılara Türkçe Öğretiminde Kültür Aktarımına Yönelik Yapılan Çalışmaların Değerlendirilmesi” isimli çalışmada, dil bilgisi yapılarının yanında kültürel ögelere de yer verilmesinin önemli olduğu belirtilmiştir. Yapılan çalışmalarda, bu önemin yeterince gösterilmediği belirtilmektedir.

Seymen ve Tok (2015) tarafından gerçekleştirilen çalışmada, ileri seviyede Türkçe bilen yabancı uyruklu öğrencilerin zorlandıkları kültürel dil unsurlarının tespiti ve sinıflandırılması yapılmıştır. Buna göre, öğrencilerin anlam bakımından en çok zorlandıkları kullanımların deyimler, kinayeler, ad aktarmaları, tevriyeler olduğu belirlenmiştir. Sonuçta deyim, atasözü, kalıp sözlerin yanı sıra edebî

\footnotetext{
Adres $\mid$ Address

İstanbul Medeniyet Üniversitesi, Eğitim Bilimleri Fakültesi, Türkçe ve Sosyal Bilimler Eğitimi Bölümü, Türkçe Eğitimi ABD Cevizli Turkish and Social Scinces Education, Turkish Language Teaching Kampüsü, Kartal-İstanbul/TÜRKIYE $\quad$ Education, Cevizli Campus, Kartal-İstanbul /TURKEY e-posta: editor@rumelide.com 1 e-mail: editor@rumelide.com
} 
Evaluation of Turkish language teaching for foreigners course programs of general directorate of lifelong learning in terms of various variables /T. Aytan; O. Uzun; Y. Günaydın ( (pp. 70-99)

dilden de yararlanmak gerektiği ortaya çıkmıştır. Söz konusu kavramlar, Türk sözlü kültürünün vazgeçilmez unsurlarıdır.

Akcaoğlu (2019) tarafından "Kültürel Aktarım Aracı Olarak Somut Olmayan Kültürel Miras" isimli çalışmada, UNESCO`nun Somut Olmayan Kültürel Miras Listesi’de yer alan ögelerin kitaplarda ne kadar ve nasıl kullanıldığını tespit etmek ve bu ögelerle ilgili öneriler sunmak amaçlandığı belirtilmiştir. Bu doğrultuda Yunus Emre Enstitüsü Yedi İklim ve Ankara Üniversitesi TÖMER Yeni Hitit Türkçe öğretim setlerinin ders kitapları tarandı ̆̆ı belirtilmektedir. Sonuç olarak, güncel durumda var olan ögelerin sayısının artırılmasının olanaklı olduğu belirtilerek Türkçe öğretimi derslerinde kültürel ögelerin nasıl kullanılacağına dair öneriler getirilmiştir.

Çelik (2018) tarafından gerçekleştirilen çalışmada, Türkiye`de öğrenim gören yabancı öğrencilerin kültürel ihtiyaçlarının belirlenmesi ve bu doğrultuda Türkçe derslerinde öncelik verilmesi gereken kültürel unsurların tespit edilmesi amaçlanmıştır. Araştırmanın sonuçlarına bakıldığında, kültür aktarımı konusunda öğretmen, ders kitabı ve ek malzemelerin oldukça önemli olduğu belirtilmektedir. İletişimsel yaklaşımla birlikte dil öğretiminde aile yapısı, Türk filmleri, Türk tiyatro ve edebiyatının aktarılması; Türk politika ve tarihinin ise belli bir seviyeden sonra ele alınması gerektiği belirtilmektedir.

Caner, Direkçi ve Kurt (2019) tarafından gerçekleştirilen çalışmada, Türkçenin yabancı dil olarak öğretiminde kültür aktarımı üzerine gerçekleştirilen çalışmaların azlığına dikkat çekilmektedir. Bununla beraber araştırmanın amacı, öğretmen adaylarının kültür aktarımına ilişkin görüşlerinin irdelenmesi olarak belirlenmiştir. Çalışmanın bulgu ve sonuç kısmında; katılımcıların büyük çoğunluğunun, yabancılara Türkçe öğretiminde Türk kültürüne yer verilmesinin olumlu sonuçlar doğuracağını, öğretici konumundaki bireylerin de öğrencilerinin dili ve kültürü hakkında bilgi sahibi olmaları gerektiğini dile getirmektedirler.

Çiftçi (2019), Yabancı Uyruklu Öğrenciler İçin Türkçe kitabındaki kültür aktarımı konusunu ele alarak inceleme gerçekleştirmiştir. Doküman incelemesi sonucunda, kültür aktarımına yönelik ögelerin 8 alana eşit ya da birbirine yakın oranda dağılmadığı dile getirilmiştir. Bu çalışmada, kültür aktarımı konusunun dar bir çerçevede ele alındığı belirtilmiştir.

Ders kitaplarında kültür aktarımını ele alan bir diğer çalışmada Kalenderoğlu (2015), kültür unsurunun yabancı dil olarak Türkçe öğretiminde oldukça önemli olduğunu dile getirerek, temel düzeyde (A1, A2) Türkçe öğrenen bireylere yönelik hazırlanan ders kitaplarındaki kültür unsurlarını tespit edip değerlendirmiştir.

Bununla beraber yabancılara Türkçe öğretiminde dil becerilerine yönelik çalışmalardan bazıları şunlardır:

Şimşek ve Aktaş (2016) tarafından gerçekleştirilen çalışmada, yabancllara Türkçe öğretiminde kullanılan İstanbul Yabancılar için Türkçe Öğretim Seti ve Yunus Emre Enstitüsü Türkçe Öğretim Seti B2 düzeyi ders kitapları temel dil becerileri, kültür aktarımı ve ünite değerlendirme ölçütleri açısından karşılaştırılmıştır. Buna göre, dinleme becerisinin diğer becerilere göre nicel olarak geri planda kaldığı, diğer becerilere gereken önemin verildiği ileri sürülmüştür. Kültür aktarımı konusunda Yunus Emre Enstitüsü Türkçe Öğretimi Seti’nin daha başarılı olduğu belirtilmiştir.

\footnotetext{
Adres $\mid$ Address

İstanbul Medeniyet Üniversitesi, Eğitim Bilimleri Fakültesi, Türkçe İstanbul Medeniyet University, Faculty of Education Sciences, ve Sosyal Bilimler Eğitimi Bölümü, Türkçe Eğitimi ABD Cevizli $\quad$ Turkish and Social Scinces Education, Turkish Language Teaching Kampüsü, Kartal-İstanbul/TÜRKIYE $\quad$ Education, Cevizli Campus, Kartal-İstanbul /TURKEY e-posta: editor@rumelide.com 1 e-mail: editor@rumelide.com
} 
Dursun (2017) tarafından gerçekleştirilen çalışmada, film kullanımının öğrencilerin anlama becerisine etkisini belirlemek amaçlanmıştır. Söz konusu çalışmanın sonucunda, öğrencilerin seyrettikleri Türkçe filmdeki karakterleri çok yönlü olarak değerlendirmede ve filmdeki olay örgüsünü çözümlemede başarılı oldukları bildirilmiştir. Dil öğretiminde film kullanımının faydalı olduğu belirtilmiştir.

Gün, Yalçın ve Pişkin (2019) tarafından gerçekleştirilen çalışmada, yabancılara Türkçe öğretimi kitaplarında yer alan dil bilgisi konuları ve etkinliklerinin karşılaştırmalı analizi gerçekleştirilmiştir. Buna göre, bazı kitapların dil bilgisi konularına ayrı bir bölümde yer verdiği, bazı kitapların ise dil bilgisi konularına diğer dil becerilerinde yer alan etkinliklerin içerisinde yer verdiği tespit edilmiştir. Ayrıca dil bilgisi alanında ele alınan konuların temel seviye konuları olduğu belirtilmiştir. Bununla beraber dil bilgisi konularının seçiminde herhangi bir standartlaşmanın olmadığı ve konuların seçiminin uzmanların tercihine bırakıldığı belirtilmektedir.

Hasırcı (2019) tarafından gerçekleştirilen çalışmada, yabancılara Türkçe öğretimine yönelik ders kitapları, konuşma becerisi açısından karşılaştırılmıştır. Buna göre, öğretmen merkezli etkinliklerin fazla olduğu ve bu durumun öğrenci merkezli etkinlikler hazırlayarak düzeltilmesi gerektiği belirtilmiştir. Ayrıca dilsel becerilerdeki bütünsellikte, okumanın yanı sıra yazma ve dinleme becerilerinin de dengeli bir biçimde ele alınması ve konuşma etkinliklerinde hazırlık sürecinin gözetilmesi gerektiği bildirilmiştir.

Mattiussi (2019) tarafından gerçekleştirilen çalışmada, yabancılara Türkçe öğretiminde dinleme becerisinin geliştirilmesine yönelik görsel-işitsel materyal kullanımı üzerine araştırma yapılmıştır. Araştırmanın sonuç verilerine göre, ses uyaran temelli olan dinleme metinlerinin, diğer uyaran desteğini görsellerle daha etkili kıldığı, altyazı uyaranlı dinleme metinlerinde öğrencilerin anlama açısından daha sınırlı bir öğretim ortamında kaldığı ortaya çıkmıştır.

\section{Araştırmanın amacı}

Yabancılara Türkçe Öğretimi, yurt içinde ve yurt dışında Türkçe öğrenmek isteyenlerin sağlıklı bir şekilde dil öğrenim süreci gerçekleştirmesi ve hedef dilin inceliklerini kavrayabilmeleri açısından oldukça önemli bir konudur. Söz konusu süreçte, dil becerisi öğretiminin yanında kültür aktarımı kavramının da bu öğretim faaliyetinin içine dâhil edilmesi gerekmektedir. Çünkü dil ve kültür birbirinden ayrılmaz parçalardır. Bu nedenle yabancılara Türkçe öğretimi alanında Diller İçin Avrupa Ortak Başvuru Metni (2001) temel alınarak hazırlanan Türkçe öğretim programlarının, ders kitaplarının ve diğer materyallerin Türkçenin kültürel zenginliğini yansıtacak şekilde hazırlanması gerekmektedir.

Siyasi, ekonomik vb. nedenlerle Türkiye’ye yerleşen mültecilerin Türkçe öğrenmelerine yönelik olarak Hayat Boyu Öğrenme Genel Müdürlüğü tarafından hazırlanan farklı yaş gruplarına yönelik programlar bulunmaktadır. Söz konusu çalışmada, hazırlanan programlar içerisinden 13-17 yaş grubuna yönelik 1, 2 ve 3. Seviye Kurs Programları temel alınmıştır. Bununla birlikte araştırmanın amacı Yabancılara Türkçe Öğretimi 1, 2 ve 3. Seviye Kurs Programlarını çeşitli değişkenler açısından inceleyerek dil öğretimi açısından mevcut durumunu ortaya koymaktır.

Söz konusu amaca ulaşmak için aşağıda yer alan alt problemlere yanıtlar aranmıştır:

- Yabancı Diller Yabancılara Türkçe Öğretimi 1, 2 ve 3. Seviye Kurs Programında yer alan kazanımların dil becerilerine göre dağılımı nasıldır?

\footnotetext{
Adres $\mid$ Address

İstanbul Medeniyet Üniversitesi, Eğitim Bilimleri Fakültesi, Türkçe İstanbul Medeniyet University, Faculty of Education Sciences, ve Sosyal Bilimler Eğitimi Bölümü, Türkce Eğitimi ABD Cevizli Turkish and Social Scinces Education, Turkish Language Teaching Kampüsü, Kartal-İstanbul/TÜRKIYE $\quad$ Education, Cevizli Campus, Kartal-İstanbul /TURKEY e-posta: editor@rumelide.com 1 e-mail: editor@rumelide.com
} 
Evaluation of Turkish language teaching for foreigners course programs of general directorate of lifelong learning in terms of various variables /T. Aytan; O. Uzun; Y. Günaydın ( (pp. 70-99)

- Yabancı Diller Yabancılara Türkçe Öğretimi 1, 2 ve 3. Seviye Kurs Programının Türk kültürüne ait ögeleri yansıtma durumu nasıldır?

\section{Araştırma modeli}

İlgili araştırma doküman analizi modeliyle yürütülmüştür. Doküman analizi bir nitel araştırma yöntemidir. Bu yöntem "Konu ile ilgili olarak alan yazında var olan yazılı materyallerin taranarak analiz edilmesini kapsamaktadı»" (Yıldırım ve Şimşek, 2013:214). Yabancılara Türkçe Öğretimi 1, 2 ve 3. Seviye Kurs Programları araştırmanın dokümanı olarak belirlenmiştir. Bununla beraber ilgili programlarda yer alan ögeler çeşitli değişkenler açısından ele alınarak incelenmiştir.

\section{Evren ve örneklem}

Araştırmanın evrenini Hayat Boyu Öğrenme Genel Müdürlüğü tarafından hazırlanan Yabancılara Türkçe Öğretimi Kurs Programları oluşturmaktadır. Araştırmada örneklem olarak ilgili programların tamamını temsil edebileceği düşünülen Yabancılara Türkçe Öğretimi 1, 2 ve 3. seviye kurs programları seçilmiştir. İlgili kurs programları 13- 17 yaş seviyesini kapsamaktadır.

\section{Verilerin analizi}

Araştırmada doküman analizi kullanılmıştır. Örneklemde ele alınan 1, 2 ve 3. seviye kurs programlarında yer alan konuların ve bu konuların altında sıralanan kazanımların dil becerilerinden hangilerine yönelik olduğunu tespit etmek, bununla beraber Türk kültürüne ait ögeleri yansitıp yansıtmadığını tespit etmek amacıyla ilgili konu ve kazanımlar incelenmiş ve elde edilen veriler tablo hâlinde sunulmuştur.

\section{Bulgular}

Bulgular, araştırmada ele alınan iki alt probleme göre isimlendirilerek aşağıda sunulmuştur.

\section{Birinci alt probleme ait bulgular}

Araştırmada ele alınan Yabancılara Türkçe Öğretimi 1, 2 ve 3.Seviye Kurs Programındaki ilgili konular ve alt başlıklarla birlikte öğrencilere kazandırılması hedeflenen davranışların birer kazanım hâlinde sunulduğu görülmektedir. İlgili programların birinci, dördüncü ve yedinci konularında yer alan kazanımlar birinci alt problem dâhilinde dil becerilerine göre gruplandırılmış hâli Tablo. 5'e verilmiştir.

\begin{tabular}{lll}
\hline Dil becerisi & $\begin{array}{l}\text { Konu. } \\
\text { alt konu. } \\
\text { kazanım } \\
\text { numarası. }\end{array}$ & Konu başlı̆̆ı/Kazanım \\
\hline & 1. & Alfabe Öğretimi \\
& 1.1. & Ses Bilgisi, Telaffuz ve Yazma Yeterliliği \\
Konuşma & 1.1 .1$. & Alfabede yer alan harfleri duyduğunda anlar ve harflere ait sesleri çıarır. \\
Dinleme/Okuma & 1.1 .2$. & Sesleri hisseder, tanır ve ayırt eder. \\
Dinleme & 1.1 .3$. & Seslerle harfleri, heceleri, sözcükleri ve görselleri eşleştirir. \\
Konuşma & 1.1 .4$. & Sesleri doğru çıkarır.
\end{tabular}

\footnotetext{
\begin{tabular}{r|l} 
Adres & Address \\
İstanbul Medeniyet Üniversitesi, Eğitim Bilimleri Fakültesi, Türkçe & İstanbul Medeniyet University, Faculty of Education Sciences,
\end{tabular} ve Sosyal Bilimler Eğitimi Bölümü, Türkce Eğitimi ABD Cevizli Turkish and Social Scinces Education, Turkish Language Teaching Kampüsü, Kartal-İstanbul/TÜRKIYE $\quad$ Education, Cevizli Campus, Kartal-İstanbul /TURKEY e-posta: editor@rumelide.com 1 e-mail: editor@rumelide.com
} 


\begin{tabular}{|c|c|c|}
\hline Okuma & 1.1.5. & Harfleri tanır ve doğru seslendirir. \\
\hline Okuma & 1.1.6. & $\begin{array}{l}\text { Görsellerle verilen kelimelerde eksik olan harfi ya da harfleri tamamlar. a-a- } \\
\text { a> araba }\end{array}$ \\
\hline Okuma & 1.1 .7 & Adı, soyadı gibi kelimeleri harf harf söyler. Ör. A-Y-L-İ-N \\
\hline Konuşma & 1.1.8. & Kelimeleri doğru telaffuz eder. \\
\hline Dinleme & 1.1.9. & Tonlama ve vurgudaki farkları ayırır. \\
\hline Okuma & 1.1.10. & Hece, kelime ve cümleleri akıcı bir şekilde okur. \\
\hline Okuma & 1.1.11. & Kısa metinleri vurgu ve tonlamaya dikkat ederek okur. \\
\hline Konuşma & 1.1.12. & Göz teması kurarak işitilebilir bir ses tonuyla konuşur. \\
\hline Yazma & 1.1.13. & $\begin{array}{l}\text { Yazma materyallerini uygun biçimde kullanarak çeşitli boyama/çizgi } \\
\text { çalışmaları yapar. }\end{array}$ \\
\hline Yazma & 1.1.14. & Harfleri, rakamları ve matematiksel işaretleri tekniğine uygun yazar. \\
\hline Okuma & 1.1.15. & Büyük ve küçük harfleri ayırt eder. \\
\hline Yazma & 1.1.16. & Dikte yoluyla harfleri ve basit kelimeleri yazar. \\
\hline Yazma & 1.1.17. & Sayfa ve yazım düzenine dikkat eder. \\
\hline Dinleme & 1.1.18. & Dinlediklerinde vurgulanan sesi tanır, ayırt eder. \\
\hline Okuma & 1.1.19. & $\begin{array}{l}\text { Bir metinde bilmediği kelimeleri belirler ve bu kelimelerin anlamlarını } \\
\text { öğrenmek için soru sorar. }\end{array}$ \\
\hline
\end{tabular}

Tablo. 5 Alfabe Öğretimi Konusu Kazanım Beceri Dağılım Tablosu

Programın ilk konusu olan “Alfabe Öğretimi” başlığı altında on dokuz kazanıma yer verilmektedir. Söz konusu bölüm, Türkçeyi öğrenmek isteyen yabancı dil öğrenicileri için temel dil becerilerini kapsayan giriş seviyesi kazanımlarından oluşmaktadır. İlgili kazanımlar beceri dağılımı açısından incelendiğinde, okuma becerisi ağırlıklı kazanımlardan oluştuğu görülmektedir. Buna göre kazanımların üç tanesi $(\% 15,78)$ dinleme becerisi, yedi tanesi $(\% 36,84)$ okuma becerisi, dört tanesi $(\% 21,05)$ konuşma becerisi, dört tanesi $(\% 21,05)$ de yazma becerisi ile ilgilidir. Bir kazanım $(\% 5,26)$ ise hem okuma hem de dinleme becerisiyle ilgilidir.

\begin{tabular}{|c|c|c|c|}
\hline Dil becerisi & $\begin{array}{l}\text { Konu. } \\
\text { alt konu. } \\
\text { kazanım } \\
\text { numarası }\end{array}$ & \multicolumn{2}{|c|}{ Konu başlı̆̆ı/Kazanım } \\
\hline & 4. & \multicolumn{2}{|c|}{ Sayılar ve Zaman } \\
\hline & 4.1. & \multicolumn{2}{|l|}{ Sayılar } \\
\hline Konuşma & 4.1.1. & \multicolumn{2}{|c|}{ Sayma sayılarını 1'den 100' e kadar sayar. } \\
\hline Yazma & 4.1.2. & \multicolumn{2}{|c|}{$\begin{array}{l}\text { Rakamla verilen sayıları yazı ile yazar. } \\
\text { Ör. 15: "On beş" }\end{array}$} \\
\hline Yazma & 4.1 .3 & \multicolumn{2}{|c|}{$\begin{array}{l}\text { Yazıyla verilen sayıları rakamla yazar. } \\
\text { Ör. “On altı” : } 16\end{array}$} \\
\hline Konuşma & 4.1 .4 & \multicolumn{2}{|c|}{$\begin{array}{l}\text { Sira sayılarını sayar. } \\
\text { Ör. “1.,2.,3.,4.,5.,..." }\end{array}$} \\
\hline \multirow[t]{2}{*}{ Dil Bilgisi } & 4.1 .5 & \multicolumn{2}{|c|}{$\begin{array}{l}\text { “-nci” ekini konuşma ve yazmada kullanır. } \\
\text { Ör. “1'inci, 2’inci, } 3 \text { 'üncü”, “5’inci öğrenci.” }\end{array}$} \\
\hline & 4.2. & \multicolumn{2}{|l|}{ Saatler } \\
\hline \multicolumn{3}{|c|}{$\begin{array}{r}\text { Adres } \\
\text { İstanbul Medeniyet Üniversitesi, Eğitim Bilimleri Fakültesi, Türkçe } \\
\text { ve Sosyal Bilimler Eğitimi Bölümü, Türkçe Eğitimi ABD Cevizli } \\
\text { Kampüsü, Kartal-İstanbul/TÜRKIYE } \\
\text { e-posta: editor@rumelide.com }\end{array}$} & $\begin{array}{l}\text { Address } \\
\text { İstanbul Medeniyet University, Faculty of Education Sciences, } \\
\text { Turkish and Social Scinces Education, Turkish Language Teaching } \\
\text { Education, Cevizli Campus, Kartal-İstanbul /TURKEY } \\
\text { e-mail: editor@rumelide.com }\end{array}$ \\
\hline
\end{tabular}


Evaluation of Turkish language teaching for foreigners course programs of general directorate of lifelong learning in terms of various variables /T. Aytan; O. Uzun; Y. Günaydın ( (pp. 70-99)

\begin{tabular}{|c|c|c|}
\hline Konuşma & 4.2 .1 & Görseli verilen saatin kaç olduğunu söyler. \\
\hline Konuşma & 4.2.2. & Saat ve saatle ilgili dakika, saniye vb. kelimeleri söyler. \\
\hline Konuşma/Yazma & 4.2.3. & Tam ve yarım saat ifadelerini öğrenir ve kullanır. \\
\hline Dil Bilgisi & $4 \cdot 2.4$ & “Saat kaç?” soru kalıbını sorar ve cevap verir. \\
\hline Konuşma/Yazma & 4.2 .5 & $\begin{array}{l}\text { "Geçiyor" ve "var" ifadelerini öğrenir ve kullanır. } \\
\text { Ör. "Maçın başlamasına 1,5 saat var." }\end{array}$ \\
\hline Konuşma & 4.2 .6$. & $\begin{array}{l}\text { "Ne zaman?” ve “saat kaçta?” soru kalıplarını öğrenir ve bunlara } \\
\text { "geçer ve kala” kelimelerini kullanarak cevap verir. } \\
\text { Ör. “Maç ne zaman?”, “Sekizi on beş geçe.”, “Ders saat kaçta?”, } \\
\text { "Dörde on kala.” }\end{array}$ \\
\hline Konuşma & 4.2 .7 & Bir günün kaç saat olduğunu söyler. \\
\hline Okuma/yazma & 4.2 .8$. & $\begin{array}{l}\text { Verilen saat görsellerinin altına saatin kaç olduğunu tam ve yarım } \\
\text { saat ifadeleriyle yazar. }\end{array}$ \\
\hline Konuşma/Yazma & 4.2 .9$. & $\begin{array}{l}\text { Günün vakitlerini cümle içinde kullanır. } \\
\text { Ör. "Sabah erken kalk!”, “Öğlen yemek ye!”, “Akşam ders çalış!” }\end{array}$ \\
\hline Okuma/Yazma & $\begin{array}{l}4.2 .10 \\
4.3 .\end{array}$ & $\begin{array}{l}\text { Verilen saat görsellerinin altına saatin kaç olduğunu yazar. } \\
\text { Günler }\end{array}$ \\
\hline Konuşma & $4 \cdot 3.1$ & $\begin{array}{l}\text { Haftanın günlerini sayar. } \\
\text { Ör. "Pazartesi, Salı,.....Pazar." }\end{array}$ \\
\hline Konuşma & $4 \cdot 3.2$. & $\begin{array}{l}\text { Bugünün, yarının ve dünün hangi gün olduğunu söyler. } \\
\text { Ör. "Bugün günlerden ne?”, "Perşembe.”, }\end{array}$ \\
\hline Konuşma & $\begin{array}{l}4 \cdot 3 \cdot 3 \cdot \\
4 \cdot 4\end{array}$ & $\begin{array}{l}\text { Hafta sonunun hangi günler olduğunu söyler. } \\
\text { Aylar ve Mevsimler }\end{array}$ \\
\hline Konuşma & $4 \cdot 4 \cdot 1$ & $\begin{array}{l}\text { Ay, yıl, hafta ve mevsimleri söyler. } \\
\text { Ör. "Ocak, Şubat........Aralık" }\end{array}$ \\
\hline Konuşma & $4 \cdot 4.2$. & Bir yılda kaç ay olduğunu söyler. \\
\hline Konuşma & $4 \cdot 4 \cdot 3$ & Mevsimlerin adlarını sırasıyla söyler. \\
\hline Konuşma & $4 \cdot 4 \cdot 4$ & $\begin{array}{l}\text { Hangi ayın hangi mevsimde olduğunu söyler. } \\
\text { Ör. "Hangi aylar kış aylarıdır? "Aralık, Ocak, Şubat”, "Ağustos } \\
\text { hangi } \\
\text { mevsimdedir?”, "Yaz.” }\end{array}$ \\
\hline Konuşma & $4 \cdot 4 \cdot 5$ & $\begin{array}{l}\text { Bir önceki veya bir sonraki ayı söyler. } \\
\text { Ör. "Nisan ayından önceki ay nedir?”, “Mart.” }\end{array}$ \\
\hline Konuşma & $4 \cdot 4 \cdot 6$. & $\begin{array}{l}\text { Mevsimlere göre hava durumunu söyler? } \\
\text { Ör. "Kış soğuktur." "Yaz sıcaktır." }\end{array}$ \\
\hline Konuşma/Yazma & $4 \cdot 4 \cdot 7$ & $\begin{array}{l}\text { ”ve , ile" bağlaçlarını kullanarak cümleler kurar. } \\
\text { Ör. "Ocak ve şubat kış aylarıdır." "Mart ile nisan ilkbahar } \\
\text { aylarıdır." }\end{array}$ \\
\hline
\end{tabular}

Tablo. 6 Sayılar ve Zaman Konusu Kazanım Beceri Dağılım Tablosu

Programın dördüncü konusu olan "Sayılar ve Zaman" başlı̆̆ altında toplam yirmi beş kazanıma yer verilmiştir. Söz konusu kazanımların on beş (\%60) tanesi konuşma becerisine, iki (\%8) tanesi yazma becerisine, iki (\%8) tanesi dil bilgisi kazanımına, dört (\%16) tanesi konuşma ve yazma becerisine aitken iki (\%8) tanesi okuma ve yazma becerisine aittir.

\footnotetext{
Adres $\mid$ Address

İstanbul Medeniyet Üniversitesi, Eğitim Bilimleri Fakültesi, Türkçe İstanbul Medeniyet University, Faculty of Education Sciences, ve Sosyal Bilimler Eğitimi Bölümü, Türkce Eğitimi ABD Cevizli Turkish and Social Scinces Education, Turkish Language Teaching Kampüsü, Kartal-İstanbul/TÜRKIYE Education, Cevizli Campus, Kartal-İstanbul /TURKEY e-posta: editor@rumelide.com 1 e-mail: editor@rumelide.com
} 


\begin{tabular}{|c|c|c|}
\hline Dil becerisi & $\begin{array}{l}\text { Konu. } \\
\text { alt konu. } \\
\text { kazanim } \\
\text { numarası }\end{array}$ & Konu başlı̆̆ı/Kazanım \\
\hline & 7. & Meslekler \\
\hline & 7.1. & Meslekleri Tanıma \\
\hline Okuma & 7.1.1. & Bir meslekle ilgili verilen görselden mesleği tanır. \\
\hline Okuma/Yazma & 7.1.2. & Mesleklerle ilgili verilen görselleri meslek isimleri ile eşleştirir. \\
\hline Konuşma & 7.1.3. & $\begin{array}{l}\text { Çevresinde sıkça kullanılan meslek isimlerini söyler. } \\
\text { Ör. "aşçı”, “öğretmen”, "bakkal”, "polis...” }\end{array}$ \\
\hline Dil Bilgisi & 7.1.4. & $\begin{array}{l}\text { "cl, -ci, -cu, -cü” eklerinin işlevini kavrar ve bu eklerle meslek } \\
\text { isimleri türetir. } \\
\text { Ör. "balık-balıkçı”, su-sucu”, "tamir-tamirci”, "temizlik- } \\
\text { temizlikçi” }\end{array}$ \\
\hline Dil Bilgisi & 7.1 .5 & $\begin{array}{l}\text { Geniş zamanı kullanarak insanların her zaman yaptığı işleri ve } \\
\text { alışkanlıklarını söyler. } \\
\text { Ör. "Sabah yedide kalkarım.”, “12’de yemek yerim.”, “Öğgleden } \\
\text { sonra futbol oynarım.” }\end{array}$ \\
\hline Dil Bilgisi & 7.1.6. & $\begin{array}{l}\text { Geniş zamanda kullanılan sıklık belirten zaman ifadelerini } \\
\text { kullanır. } \\
\text { Ör. "Sık sık şehir dışına çıkarım.”, "Her zaman erken kalkarım.”, } \\
\text { "Her sabah/akşam/gün..." }\end{array}$ \\
\hline Konuşma & 7.1.7. & $\begin{array}{l}\text { Meslek sahiplerinin ne iş yaptığını söyler. } \\
\text { Ör. “Aşçı yemek yapar.”, "Sucu su dağıtır.” }\end{array}$ \\
\hline Konuşma & 7.1.8. & $\begin{array}{l}\text { Hayalindeki mesleği söyler ve karşısındaki kişiye hayalindeki } \\
\text { mesleğini sorar. }\end{array}$ \\
\hline Okuma & 7.1.9. & Bir metinde geçen meslek isimlerini tespit eder. \\
\hline Dil Bilgisi & 7.1.10. & $\begin{array}{l}\text { Sonu sert ünsüzlerle (f, s, t, k, ç, ş, h, p) biten kelimelerin “c, d, } \\
\text { g” ile başlayan ek aldığında “ç, t, k" ya dönüştüğünü ö̆ğrenir. } \\
\text { Ör. "kitap-kitapçı, kitap-kitapta” }\end{array}$ \\
\hline
\end{tabular}

Tablo. 7 Meslekler Konusu Kazanım Beceri Dağılım Tablosu

Programın yedinci konusu olan "Meslekler" başlı̆̆ı altında toplam on kazanıma yer verilmiştir. Söz konusu kazanımların dört (\%40) tanesi dil bilgisine, üç (\%30) tanesi konuşma becerisine, iki (\%20) tanesi okuma becerisine, bir (\%10) tanesi okuma ve yazma becerisine aittir.

Yabancılara Türkçe Öğretimi 2. Seviye Kurs Programında "Giriş” konusu altında yer alan kazanımlara ait bulgular aşağıdaki Tablo. 8 `de yer almaktadır.

\begin{tabular}{|c|c|c|c|}
\hline Dil becerisi & $\begin{array}{l}\text { Konu. } \\
\text { alt konu. } \\
\text { kazanim } \\
\text { numaras }\end{array}$ & \multicolumn{2}{|c|}{ Konu başlı̆̆ı/Kazanım } \\
\hline & 1. & \multicolumn{2}{|l|}{ Giriş } \\
\hline Konuşma & 1.1. & \multicolumn{2}{|c|}{ Türk dilinin alfabesini bilir; sesleri doğru çıkarır. } \\
\hline Konuşma & 1.2. & \multicolumn{2}{|c|}{ Karşısındaki ile selamlaşır ve kendini tanıtır. } \\
\hline Konuşma/Yazma & 1.3 . & \multicolumn{2}{|c|}{ Okulu, evi ve çevresi ile ilgili bilgi verir. } \\
\hline Konuşma & 1.4 . & \multicolumn{2}{|c|}{ 1'den 100'e kadar sayma ve sıra sayılarını sayar. } \\
\hline \multicolumn{3}{|c|}{$\begin{array}{r}\text { Adres } \\
\text { İstanbul Medeniyet Üniversitesi, Eğitim Bilimleri Fakültesi, Türkçe } \\
\text { ve Sosyal Bilimler Eğitimi Bölümü, Türkçe Eğitimi ABD Cevizli } \\
\text { Kampüsü, Kartal-İstanbul/TÜRKiYE } \\
\text { e-posta: editor@rumelide.com }\end{array}$} & $\begin{array}{l}\text { Address } \\
\text { İstanbul Medeniyet University, Faculty of Education Sciences, } \\
\text { Turkish and Social Scinces Education, Turkish Language Teaching } \\
\text { Education, Cevizli Campus, Kartal-İstanbul /TURKEY } \\
\text { e-mail: editor@rumelide.com }\end{array}$ \\
\hline
\end{tabular}


Evaluation of Turkish language teaching for foreigners course programs of general directorate of lifelong learning in terms of various variables /T. Aytan; O. Uzun; Y. Günaydın ( (pp. 70-99)

\begin{tabular}{|c|c|c|}
\hline Konuşma & 1.5 . & $\begin{array}{l}\text { Saati sorar ve söyler. Gün, ay, yll, mevsim gibi zaman ile ilgili } \\
\text { kelime ve ifadeleri kullanır. }\end{array}$ \\
\hline Konuşma/Yazma & 1.6. & Vücudun organlarını ve kişisel bakım eşyalarını söyler ve yazar. \\
\hline Konuşma/Yazma & 1.7 . & $\begin{array}{l}\text { Günlük temel ihtiyaçlardan olan yiyecek, içecek ve kıyafetlerin } \\
\text { isimlerini söyler ve yazar. }\end{array}$ \\
\hline Konuşma/Yazma & 1.8. & Çevresindeki eşyaların renklerini söyler ve yazar. \\
\hline Konuşma/Dil Bilgisi & 1.9 . & $\begin{array}{l}\text { Her zaman yaptığı işleri sıklık bildiren zaman ifadeleriyle } \\
\text { anlatır. }\end{array}$ \\
\hline Konuşma & 1.10 . & $\begin{array}{l}\text { Başlıca meslekleri bilir ve meslek sahiplerinin ne yaptıklarını } \\
\text { söyler. }\end{array}$ \\
\hline Konuşma & 1.11. & Ürünlerin fiyatlarını sorar. \\
\hline
\end{tabular}

Tablo. 8 Giriş Konusu Kazanım Beceri Dağılım Tablosu

2.Seviye Kurs Programın birinci konusu olan "Giriş" başlı̆̆ altında toplam on bir kazanıma yer verilmiştir. Söz konusu kazanımların altı $(\% 54,545)$ tanesi konuşma becerisine, dört $(\% 36,36)$ tanesi konuşma ve yazma becerisine, bir (\%9,09) tanesi konuşma ve dil bilgisi becerisine aittir.

\begin{tabular}{|c|c|c|}
\hline Dil becerisi & $\begin{array}{l}\text { Konu. } \\
\text { alt konu. } \\
\text { kazanim } \\
\text { numarası }\end{array}$ & Konu başlığı/Kazanım \\
\hline & 4. & Günlük Hayat ve Etkinlikler \\
\hline & 4.1. & Şu Anda Yaptıklarım \\
\hline Dil Bilgisi & 4.1.1. & Fiillerde zaman kavramı hakkında bilgi edinir. \\
\hline Dil Bilgisi & 4.1 .2$. & $\begin{array}{l}\text { Şahıs zamirleriyle bir fiili şimdiki zamanda çekimler. } \\
\text { Ör. "Ben okuyorum, sen okuyorsun, o okuyor; biz okuyoruz, siz } \\
\text { okuyorsunuz, onlar okuyorlar.” }\end{array}$ \\
\hline Dil Bilgisi & 4.1 .3 & $\begin{array}{l}\text { Şu an yaptığı işleri şimdiki zaman eki “-yor”u kullanarak anlatır. } \\
\text { Ör. "Bisiklete biniyorum”, "Parkta oturuyoruz." }\end{array}$ \\
\hline Dil Bilgisi & 4.1 .4 & $\begin{array}{l}\text { Şu an yapılan işleri şimdiki zaman eki “-yor”u kullanarak sorar. } \\
\text { Ör. "Ne yapıyorsun?”, “Nereye gidiyorsun?” }\end{array}$ \\
\hline \multirow[t]{2}{*}{ Dil Bilgisi } & 4.1 .5 & $\begin{array}{l}\text { Sınıfta kendisi ve arkadaşlarının neler yaptıklarını şahıs ve } \\
\text { zaman eklerini doğru kullanarak anlatır. }\end{array}$ \\
\hline & & $\begin{array}{l}\text { Ör. "Ben kitap okuyorum.”, “Ayşe resim yapıyor.”, "Sen camdan } \\
\text { dışarı bakıyorsun.” }\end{array}$ \\
\hline \multirow[t]{2}{*}{ Dil Bilgisi } & 4.1.6. & $\begin{array}{l}\text { Şimdiki zaman ekine bağlı olarak ünlü daralmasını öğrenir ve } \\
\text { uygular. }\end{array}$ \\
\hline & & Ör "bekleyor- bekliyor.”, "arayor- arıyor.” \\
\hline Dil Bilgisi & 4.1 .7 & $\begin{array}{l}\text { Şimdiki zaman eki “-yor”un ünlü uyumuna uymadığını kavrar. } \\
\text { Ör. “Geliyor.” }\end{array}$ \\
\hline \multirow[t]{2}{*}{ Dil Bilgisi } & 4.1.8. & $\begin{array}{l}\text { Bir cümledeki sonu boş bırakılan fiili şimdiki zaman ve şahıs } \\
\text { ekiyle tamamlar. }\end{array}$ \\
\hline & & $\begin{array}{l}\text { Ör. "Onlar top ........(oynamak)-oynuyorlar.”, “... tiyatroya } \\
\text { gidiyorlar.” }\end{array}$ \\
\hline Yazma & 4.1 .9$. & $\begin{array}{l}\text { "şimdi”, "şu an”, "şu anda” kelimelerini kullanır. } \\
\text { Ör. "Şimdi çalışıyorum.” }\end{array}$ \\
\hline Dil Bilgisi & 4.1.10. & Olumsuzluk eki “-ma,-me”nin şimdiki zamanda ünlü \\
\hline
\end{tabular}

\footnotetext{
\begin{tabular}{r|l} 
Adres & Address \\
İstanbul Medeniyet Üniversitesi, Eğitim Bilimleri Fakültesi, Türkçe & İstanbul Medeniyet University, Faculty of Education Sciences,
\end{tabular} ve Sosyal Bilimler Eğitimi Bölümü, Türkce Eğitimi ABD Cevizli Turkish and Social Scinces Education, Turkish Language Teaching Kampüsü, Kartal-İstanbul/TÜRKIYE $\quad$ Education, Cevizli Campus, Kartal-İstanbul /TURKEY e-posta: editor@rumelide.com 1 e-mail: editor@rumelide.com
} 


\begin{tabular}{|c|c|c|}
\hline Dil Bilgisi & 4.1.11. & $\begin{array}{l}\text { Bir fiili şimdiki zamanda olumsuz olarak çekimler. } \\
\text { Ör. “yüzmüyorum, yüzmüyorsun, yüzmüyor.” }\end{array}$ \\
\hline Dil Bilgisi & 4.1.12. & $\begin{array}{l}\text { Şimdiki zamanda olumlu çekimlenmiş fiilleri olumsuz yapar. } \\
\text { Ör. "seviyorum-sevmiyorum”, "gülüyorum-gülmüyorum.” }\end{array}$ \\
\hline \multirow[t]{3}{*}{ Dil Bilgisi } & 4.1.13. & $\begin{array}{l}\text { "etmek-gitmek-tatmak-gütmek” fiillerinin istisnai olarak } \\
\text { yumuşadığını öğrenir. }\end{array}$ \\
\hline & & Ör. "gitiyor-gidiyor", “etiyor-ediyor.” \\
\hline & 4.2. & Adres \\
\hline Konuşma & 4.2.1. & $\begin{array}{l}\text { Adres için gerekli olan mahalle, cadde, sokak gibi kelimeleri } \\
\text { söyler. }\end{array}$ \\
\hline Konuşma & 4.2.2. & $\begin{array}{l}\text { Evinin veya okulunun adresini bilir ve söyler. Ör. "Gülen } \\
\text { Muharrem Pakoğlu Ortaokulu, Emek Mah., 8. Cadde, No: } 9 \\
\text { Çankaya / Ankara.” }\end{array}$ \\
\hline Konuşma & $4 \cdot 2.3$ & $\begin{array}{l}\text { "Aşağı, yukarı, ileri, geri, sağa, sola" gibi yer yön bildiren } \\
\text { kelimelerle bir yeri tarif eder. Ör. "Parka gitmek için } 100 \text { metre } \\
\text { ileri git, sonra sağa dön, park } 50 \text { metre ileride solda." }\end{array}$ \\
\hline Yazma & $4 \cdot 2.4$ & Mektup, dilekçe gibi metinlere adresini yazar. \\
\hline Dinleme/Konuşma & 4.2.5. & Verilen bir adresi anlar ve anlatır. \\
\hline
\end{tabular}

Tablo. 9 Günlük Hayat ve Etkinlikler Konusu Kazanım Beceri Dağılım Tablosu

2.Seviye Kurs Programın dördüncü konusu olan “Günlük Hayat ve Etkinlikler” başlı̆̆ altında toplam on dört kazanıma yer verilmiştir. Söz konusu kazanımların altı $(\% 42,85)$ tanesi konuşma becerisine, altı $(\% 42,85)$ tanesi dil bilgisi becerisine, bir $(\% 7,14)$ tanesi konuşma ve yazma becerisine, bir $(\% 7,14)$ tanesi konuşma ve dil bilgisi becerilerine aittir.

\begin{tabular}{|c|c|c|}
\hline Dil becerisi & $\begin{array}{l}\text { Konu. } \\
\text { alt konu. } \\
\text { kazanim } \\
\text { numarası }\end{array}$ & Konu başlı̆̆ı/Kazanım \\
\hline & 7. & Kutlamalar ve Tatil \\
\hline & 7.1. & Özel Günler \\
\hline \multirow[t]{2}{*}{ Konuşma } & 7.1 .1 & $\begin{array}{l}\text { Doğum günü, yılbaşı, dinî ve millî bayramlarla ilgili cümleler } \\
\text { söyler. }\end{array}$ \\
\hline & & $\begin{array}{l}\text { Ör. "Bugün benim doğum günüm”, "Yarın Cumhuriyet } \\
\text { Bayramı.", "Kurban Bayramı tatil.” }\end{array}$ \\
\hline \multirow[t]{2}{*}{ Konuşma } & 7.1.2. & Özel günlerde ne yapacağını söyler. \\
\hline & & $\begin{array}{l}\text { Ör. "Arkadaşıma doğum günü için hediye alacağım”, "Bugün } \\
\text { bayram, erken kalkın çocuklar.” }\end{array}$ \\
\hline \multirow[t]{2}{*}{ Yazma } & 7.1 .3 & Özel günlerle ilgili kısa bir diyalog yazar. \\
\hline & 7.2. & Kutlamalar \\
\hline Okuma & 7.2 .1 & $\begin{array}{l}\text { Belli başlı kutlama kelimelerini öğrenir. } \\
\text { Ör. "Bayramın kutlu olsun”, "Bayramınızı tebrik ederim.”, “İyi } \\
\text { ki doğdun.” }\end{array}$ \\
\hline Yazma & 7.2 .2$. & Basit bir kutlama mesajı yazar. \\
\hline Konuşma & 7.2 .3 & Bir arkadaşının doğum gününü kutlar. \\
\hline
\end{tabular}


Evaluation of Turkish language teaching for foreigners course programs of general directorate of lifelong learning in terms of various variables /T. Aytan; O. Uzun; Y. Günaydın ( (pp. 70-99)

\begin{tabular}{|c|c|c|}
\hline Okuma- Dinleme & 7.2.4. & Bir kutlamayı telefonla nasıl yapacağını öğrenir. \\
\hline Okuma- Yazma & 7.2.5. & $\begin{array}{l}\text { Karışık olarak verilmiş davet, teklif ve tebrik içeren cümleleri } \\
\text { sıraya koyar. }\end{array}$ \\
\hline Okuma & 7.2.6. & Bir davetiye aldığında davetiyedeki bilgileri anlar. \\
\hline \multirow[t]{2}{*}{ Yazma } & 7.2 .7 & Kalıplaşmış ifadelerle basit bir davetiye yazar. \\
\hline & $7 \cdot 3$. & Tatil \\
\hline Okuma & 7.3.1. & $\begin{array}{l}\text { Tatil ve seyahatle ilgili kelimeleri öğrenir. } \\
\text { Ör. "gezi, tur, rehber, tatil, otel, gezi planı, bilet, varış, ayrılış...” }\end{array}$ \\
\hline Okuma & 7.3.2. & $\begin{array}{l}\text { Bir metinde geçen tatil ve seyahat ile ilgili bilmediği kelimeleri } \\
\text { sözlükten bulur. }\end{array}$ \\
\hline Okuma-Yazma & 7.3.3. & Tatille ilgili görselleri isimleriyle eşleştirir. \\
\hline Okuma-Yazma & & Karışık olarak verilmiş bir tatil diyaloğunu düzenler. \\
\hline Dil Bilgisi & 7.3.4. & $\begin{array}{l}\text { "Nereye?" sorusuna yönelme hâl eklerini kullanarak cevap verir. } \\
\text { Ör."Nereye gidiyorsun?”, " Okula gidiyorum.” }\end{array}$ \\
\hline Dil Bilgisi & 7.3.5. & $\begin{array}{l}\text { Konuşmalarında “-a/-e kadar” kalıbını kullanır. } \\
\text { Ör. “Akşama kadar dinleneceğim.”, "Otele kadar yürüyeceğim.”, } \\
\text { "Saat üçe kadar gel.” }\end{array}$ \\
\hline \multirow[t]{2}{*}{ Dil Bilgisi } & 7.3.6. & $\begin{array}{l}\text { Yönelme hâlini ve “-a/-e kadar” kalıbını doğru kullanarak basit } \\
\text { bir tatil planı yazar. }\end{array}$ \\
\hline & & $\begin{array}{l}\text { Ör. "Hafta sonu Marmaris’e gideceğim. Orada denize } \\
\text { gireceğim.", "Akşama kadar plajda kalacağım.", "Bir hafta sonra } \\
\text { Ankara'ya döneceğim." }\end{array}$ \\
\hline Yazma & 7.3.7. & Otellerde giriş ve kayıt formlarını doldurur. \\
\hline \multirow[t]{2}{*}{ Yazma } & 7.3.8. & $\begin{array}{l}\text { Kaynaştırma ünsüzü “y”yi kullanarak cümleler yazar. } \\
\text { Ör. “Ankara'ya gidiyorum.”, “Denizli’ye gidiyorum.” }\end{array}$ \\
\hline & 7.4 . & Müzik \\
\hline Okuma-Yazma & 7.4.1. & Görsellerde gördüğü müzik aletlerini isimleriyle eşleştirir. \\
\hline Dil Bilgisi & 7.4.2. & $\begin{array}{l}\text { Şahıs eklerini de kullanarak bir fiili gelecek zamanda çekimler. } \\
\text { Ör. "Ben geleceğim, Sen geleceksin, O gelecek...” }\end{array}$ \\
\hline Yazma & 7.4.3. & $\begin{array}{l}\text { Gelecekte yapacağı veya yapmayacağı işlerle ilgili cümleler } \\
\text { kurar. }\end{array}$ \\
\hline & & $\begin{array}{l}\text { Ör. "Akşam konser vereceğim.", "Saz çalacağım”, "Artık } \\
\text { sevmeyeceğim”, "Gitar çalmayacağım." }\end{array}$ \\
\hline Dil Bilgisi & 7.4.4. & $\begin{array}{l}\text { Gelecek zamanın olumlusu ile kurulmuş cümlelerdeki fiili } \\
\text { olumsuz yapar. }\end{array}$ \\
\hline & & Ör. “Konsere gideceğim $\square$ Konsere gitmeyeceğim.” \\
\hline Dil Bilgisi & 7.4.5. & $\begin{array}{l}\text { Gelecek zamanla ilgili sorular sorar. } \\
\text { Ör. “Sahneye çıkacak mısın?”, "Şarkı söyleyecek misin?” }\end{array}$ \\
\hline Dil Bilgisi & 7.4.6. & $\begin{array}{l}\text { Bir metinde geçen gelecek zamanla çekimlenmiş fiilleri tespit } \\
\text { eder. }\end{array}$ \\
\hline Konuşma & 7.4.7. & En sevdiği şarkıyı ve şarkıcıyı söyler. \\
\hline Okuma & 7.4.8. & Bir metinde geçen müzikle ilgili kelimeleri işaretler. \\
\hline Konuşma & 7.4.9. & Seviyeye uygun Türkçe şarkıları söyler. \\
\hline
\end{tabular}

Tablo. 10 Kutlamalar ve Tatil Konusu Kazanım Beceri Dağılım Tablosu 
2.Seviye Kurs Programın yedinci konusu olan "Kutlamalar ve Tatil" başlığı altında toplam yirmi sekiz kazanıma yer verilmiştir. Söz konusu kazanımların yedi (\%25) tanesi dil bilgisi becerisine, beş $(\% 17,85)$ tanesi konuşma becerisine, altı $(\% 21,42)$ tanesi yazma becerisine, beş $(\% 17,85)$ tanesi okuma becerisine, dört $(\% 14,28)$ tanesi okuma-yazma becerisine, bir $(\% 4,76)$ tanesi okuma-dinleme becerilerine aittir.

\begin{tabular}{lll}
\hline Dil becerisi & $\begin{array}{l}\text { Konu. } \\
\text { alt konu. } \\
\text { kazanım } \\
\text { numarası }\end{array}$ & Konu başlı̆̆ı/Kazanım \\
\hline Konuşma & 1. & GíRiş \\
Konuşma/Yazma & 1.1. & Ürünlerin isimlerini bilir, fiyatlarını sorar ve alışveriş yapar. \\
Konuşma & 1.2. & Sağlık ve spor konularında basit cümleler kurar. \\
Konuşma & 1.3. & Şu anda yaptı̆̆ı veya yapmadığı işleri söyler. \\
Yazma & 1.4. & Yer ve yön tarifi yapar, yapılan tarifi anlar. \\
Konuşma & 1.5. & Dilekçe form veya mektuplara adreslerini yazar. \\
Konuşma & 1.6. & $\begin{array}{l}\text { Alışkanlıkları, hobileri, fobileri ve yapmaktan hoşlandığı } \\
\text { etkinlikleri söyler. }\end{array}$ \\
Okuma-Dinleme & 1.7. & Zorunluluk bildiren durumları ifade eder. \\
Okuma-Dinleme & 1.8. & Hava durumuna ilişkin ifadeleri anlar. \\
Konuşma/Yazma & 1.9. & Günlük hayatta kullanılan iletişim araçlarını tanır. \\
Konuşma & 1.10. & $\begin{array}{l}\text { Resmî ve özel günler ile millî bayramları bilir, uygun ifadelerle } \\
\text { kutlar. }\end{array}$ \\
& 1.11. & $\begin{array}{l}\text { Tatil ve seyahate ilişkin temel kelimeleri kullanarak planlarını } \\
\text { söyler. }\end{array}$
\end{tabular}

Tablo. 11 Giriş Konusu Kazanım Beceri Dağılım Tablosu

3.Seviye Kurs Programın birinci konusu olan "Giriş" başlı̆̆ altında toplam on bir kazanıma yer verilmiştir. Söz konusu kazanımların altı $(\% 54,54)$ tanesi konuşma becerisine, bir $(\% 9,09)$ tanesi yazma becerisine, iki $(\% 18,18)$ tanesi okuma-dinleme becerisine, iki $(\% 14,28)$ tanesi konuşma-yazma becerisine aittir.

\begin{tabular}{|c|c|c|c|}
\hline Dil becerisi & $\begin{array}{l}\text { Konu. } \\
\text { alt konu. } \\
\text { kazanim } \\
\text { numarasi }\end{array}$ & \multicolumn{2}{|c|}{ Konu başlı̆̆ı/Kazanım } \\
\hline & 4. & \multicolumn{2}{|c|}{ Eğitim ve Çalışma Hayatı } \\
\hline & 4.1. & \multicolumn{2}{|l|}{ Eğitim } \\
\hline Konuşma & 4.1.1. & \multicolumn{2}{|c|}{ Eğitim geçmişi hakkında bilgi verir. } \\
\hline Konuşma & 4.1 .2$. & \multicolumn{2}{|c|}{$\begin{array}{l}\text { Ĕgitim ve öğrenim hayatı ile ilgili cümleler kurar. } \\
\text { Ör. "Ben yurtta kalıyorum.”, "Kütüphanede ders çalışıyorum.” }\end{array}$} \\
\hline Okuma & $4 \cdot 1 \cdot 3$ & \multicolumn{2}{|c|}{$\begin{array}{l}\text { Okul hayatı veya bir öğrenci ile ilgili bir metni okur ve ilgili } \\
\text { sorulara cevap verir. }\end{array}$} \\
\hline Konuşma & 4.1 .4 & \multicolumn{2}{|c|}{ Eğitim veren kurumları söyler. } \\
\hline Konuşma & 4.1 .5 & \multicolumn{2}{|c|}{$\begin{array}{l}\text { Eğitim kurumlarında çalışan personellerin unvanlarını söyler. } \\
\text { Ör. “Ö̈ğretmen, Okul Müdürü, Müdür Yardımcısı, Rehber }\end{array}$} \\
\hline \multicolumn{3}{|c|}{$\begin{array}{r}\text { Adres } \\
\text { İstanbul Medeniyet Üniversitesi, Eğitim Bilimleri Fakültesi, Türkçe } \\
\text { ve Sosyal Bilimler Eğitimi Bölümü, Türkçe Eğitimi ABD Cevizli } \\
\text { Kampüsü, Kartal-İstanbul/TÜRKIYE } \\
\text { e-posta: editor@rumelide.com }\end{array}$} & $\begin{array}{l}\text { Address } \\
\text { İstanbul Medeniyet University, Faculty of Education Sciences, } \\
\text { Turkish and Social Scinces Education, Turkish Language Teaching } \\
\text { Education, Cevizli Campus, Kartal-İstanbul /TURKEY } \\
\text { e-mail: editor@rumelide.com }\end{array}$ \\
\hline
\end{tabular}


Evaluation of Turkish language teaching for foreigners course programs of general directorate of lifelong learning in terms of various variables /T. Aytan; O. Uzun; Y. Günaydın ( (pp. 70-99)

\begin{tabular}{|c|c|c|}
\hline & & Öğretmen.” \\
\hline Konuşma & 4.1.6. & İleride nasıl bir eğitim almak istediğini kısaca anlatır. \\
\hline \multirow[t]{2}{*}{ Dil Bilgisi } & 4.1.7. & $\begin{array}{l}\text { Niçin, neden, ne zaman, nasıl, ne kadar vb.” soru zarflarını } \\
\text { kullanarak sorular sorar. }\end{array}$ \\
\hline & & $\begin{array}{l}\text { Ör. "Okula ne zaman gidiyorsun?”, “Ödevlerini nasıl } \\
\text { yapıyorsun?", "Öğretmen ne kadar ödev veriyor?” }\end{array}$ \\
\hline Dil Bilgisi & 4.1.8. & Bir metinde geçen soru zarflarını tespit eder. \\
\hline Dil Bilgisi & 4.1.9. & Soru zarflarını kullanarak küçük diyaloglar kurar. \\
\hline \multirow[t]{2}{*}{ Dil Bilgisi } & 4.1.10. & Boşluklara uygun soru zarfları yazar. \\
\hline & 4.2. & İş ve Meslekler \\
\hline Konuşma & 4.2.1. & Mesleklerin isimlerini sayar. \\
\hline Yazma & 4.2.2. & Resimleri verilen mesleklerin altına isimlerini yazar. \\
\hline Konuşma & 4.2 .3 & Kendi işiyle ilgili konuşur. \\
\hline Dil Bilgisi & 4.2 .4 & $\begin{array}{l}\text { Mesleklerin özelliklerini uygun sıfatlar kullanarak belirtir. } \\
\text { Ör. “yorucu”, “sıkıcı”, “zor”, "kolay”, “eğlenceli” }\end{array}$ \\
\hline Konuşma & 4.2 .5 & $\begin{array}{l}\text { Hayalini kurduğu meslekle ilgili cümleler kurar. } \\
\text { Ör. "İnsanları yangından kurtarmak için itfaiyeci olmak } \\
\text { istiyorum.” }\end{array}$ \\
\hline Dinleme-Okuma & 4.2 .6$. & Güvenlik ile ilgili uyarıları anlar \\
\hline Yazma & 4.2 .7 & Hayalini kurduğu mesleğe ilişkin kısa bir paragraf yazar. \\
\hline Yazma & 4.2 .8 . & $\begin{array}{l}\text { Bir iş başvuru formundaki gerekli bilgileri doldurur. } \\
\text { Ör. "Ad, soyad, iletişim bilgileri, doğum tarihi, tecrübe vb.” }\end{array}$ \\
\hline Dil Bilgisi & 4.2.9. & Edatların görevini ve işlevini öğrenir. \\
\hline \multirow[t]{3}{*}{ Dil Bilgisi } & 4.2.10. & $\begin{array}{l}\text { Sık kullanılan edatlardan "beri, bir tek, göre, önce, sonra, } \\
\text { yalnız...vb." cümle içinde kullanır. }\end{array}$ \\
\hline & & $\begin{array}{l}\text { Ör. "Bilgisayarın tamirini yalnız o yapabilir.”, "İşten sonra eve } \\
\text { dön.”, }\end{array}$ \\
\hline & & "Çalışmaya başlamadan önce masamın üzerini düzenlerim." \\
\hline Dil Bilgisi & 4.2.11. & Bir metinde geçen edatları tespit eder. \\
\hline Dil Bilgisi & 4.2.12. & Metindeki boşluklara uygun edatlar yazar. \\
\hline Dil Bilgisi & 4.2.13. & Hangi edatın nerede kullanılacağını ayırt eder. \\
\hline Dil Bilgisi & 4.2.14. & Edatlarla bağlaçlar arasındaki farkı ayırt eder. \\
\hline
\end{tabular}

Tablo. 12 Eğitim ve Çalışma Hayatı Konusu Kazanım Beceri Dağılım Tablosu

3.Seviye Kurs Programın dördüncü konusu olan "Eğitim ve Çalışma Hayatı" başlığı altında toplam yirmi dört kazanıma yer verilmiştir. Söz konusu kazanımların on bir $(\% 45,83)$ tanesi dil bilgisi becerisine, sekiz $(\% 33,3)$ tanesi konuşma becerisine, üç $(\% 12,50)$ tanesi yazma becerisine, bir $(\% 4,17)$ tanesi okuma becerisine, bir $(\% 4,17)$ tanesi dinleme- okuma becerisine aittir.

\begin{tabular}{|c|c|c|c|}
\hline Dil becerisi & $\begin{array}{l}\text { Konu. } \\
\text { alt konu. } \\
\text { kazanim } \\
\text { numarasi }\end{array}$ & \multicolumn{2}{|c|}{ Konu başlığı/Kazanım } \\
\hline & 7. & \multicolumn{2}{|c|}{ Duygular ve Sanat } \\
\hline & 7.1. & \multicolumn{2}{|c|}{ Duygular } \\
\hline \multicolumn{3}{|c|}{$\begin{array}{r}\text { Adres } \\
\text { İstanbul Medeniyet Üniversitesi, Eğitim Bilimleri Fakültesi, Türkçe } \\
\text { ve Sosyal Bilimler Eğitimi Bölümü, Türkçe Eğitimi ABD Cevizli } \\
\text { Kampüsü, Kartal-İstanbul/TÜRKIYY } \\
\text { e-posta: editor@rumelide.com }\end{array}$} & $\begin{array}{l}\text { Address } \\
\text { İstanbul Medeniyet University, Faculty of Education Sciences, } \\
\text { Turkish and Social Scinces Education, Turkish Language Teaching } \\
\text { Education, Cevizli Campus, Kartal-İstanbul /TURKEY } \\
\text { e-mail: editor@rumelide.com }\end{array}$ \\
\hline
\end{tabular}




\begin{tabular}{|c|c|c|}
\hline Konuşma & 7.2. & $\begin{array}{l}\text { Duygularla ilgili kelimeleri söyler. } \\
\text { Ör. "sevinç, öfke, korku, üzüntü, hoşlanma, utanma, acıma vb." }\end{array}$ \\
\hline Okuma & $7 \cdot 3$. & Görselleri verilen duyguların adlarını söyler. \\
\hline Okuma & $7 \cdot 4$. & Verilen kelimelerle duygu ifade eden resimleri eşleştirir. \\
\hline Konuşma & $7 \cdot 5$ & $\begin{array}{l}\text { Duygusal ifadeleri içeren kelimeler ile cümleler kurar. } \\
\text { Ör. "Çocuklar ağlayınca çok üzülürüm.”, “Türkçeyi öğrenmeye } \\
\text { hevesliyim.”, "Hayvanları incitenlere kızarım.” }\end{array}$ \\
\hline \multirow[t]{3}{*}{ Dil Bilgisi } & 7.6. & $\begin{array}{l}\text { Etken ve edilgen fiilleri cümle içinde kullanır. } \\
\text { Ör. "Ahmet kediyi sevdi. } \square \text { Kedi sevildi.” } \\
\text { "Öğretmen öğrencilerin başarısıyla gururlandı. } \square \text { Öğrencilerin } \\
\text { başarısıyla gururlanıldı.” }\end{array}$ \\
\hline & & $\begin{array}{l}\text { "Sı̆̆ınmacılar Türkiye'den memnun oldu. } \square \text { Türkiye’den } \\
\text { memnun olundu." }\end{array}$ \\
\hline & 7.2 . & Güzel Sanatlar \\
\hline Konuşma & 7.2.1. & $\begin{array}{l}\text { Güzel sanatların neler olduğunu söyler. } \\
\text { Ör. "resim, müzik, heykeltıraşlık, mimarlık, edebiyat, musiki..." }\end{array}$ \\
\hline Konuşma & 7.2.2. & $\begin{array}{l}\text { Resim, müzik, tiyatro ve benzeri konularda konuşmalara } \\
\text { hazırlık yaparak katılır. Fikirlerini söyler, öneride bulunur. }\end{array}$ \\
\hline Yazma & 7.2.3. & $\begin{array}{l}\text { İzlediği bir konser veya tiyatro oyunuyla ilgili arkadaşlarına e- } \\
\text { posta yazar. }\end{array}$ \\
\hline \multirow[t]{2}{*}{ Dil Bilgisi } & 7.2.4 & $\begin{array}{l}\text { Ayrılma hâl eklerini (-den, -dan....) konuşmalarında kullanır. } \\
\text { Ör. "Okuldan kütüphaneye gideceğim.”, "Resim yapmaktan } \\
\text { hoşlanırım.” }\end{array}$ \\
\hline & & "Konserden sonra arkadaşlarımla fotoğraf galerisine gideceğiz." \\
\hline
\end{tabular}

Tablo. 13 Duygular ve Sanat Konusu Kazanım Beceri Dağılım Tablosu

3.Seviye Kurs Programın yedinci konusu olan "Duygular ve Sanat" başlığı altında toplam dokuz kazanıma yer verilmiştir. Söz konusu kazanımların dört $(\% 44,4)$ tanesi konuşma becerisine, iki $(\% 22,2)$ tanesi dil bilgisi becerisine, iki $(\% 22,2)$ tanesi okuma becerisine, bir (\%11,1)tanesi yazma becerisine aittir.

\section{2. İkinci alt probleme ait bulgular}

Araştırmanın ikinci alt problemi olan "Yabancı Diller Yabancılara Türkçe Öğretimi 1, 2 ve 3. Seviye Kurs Programının Türk kültürüne ait ögeleri yansıtma durumu nasıldır?” sorusuna yönelik olarak çalışmada elde edilen bulgulara bu bölümde yer verilmektedir. İlgili programda Türk kültürüne ait ögeleri yansıtan kazanımlar aşağıdaki tabloda yer almaktadır.

\begin{tabular}{|c|c|c|}
\hline $\begin{array}{l}\text { Kurs } \\
\text { seviyesi }\end{array}$ & $\begin{array}{l}\text { Konu } \\
\text { başlığ1 }\end{array}$ & Kazanım \\
\hline 1.Seviye & $\begin{array}{l}\text { Tanışma ve } \\
\text { Arkadaşlık }\end{array}$ & $\begin{array}{l}\text { 2.1.1.Selam verir ve alır. Kişilerin hâl ve hatırını sorar. } \\
\text { Ör. "Merhaba.", "Günaydın.", "Nasılsınız?" }\end{array}$ \\
\hline 1.Seviye & $\begin{array}{l}\text { Tanışma ve } \\
\text { Arkadaşlık }\end{array}$ & $\begin{array}{l}\text { 2.1.2.Vedalaşma cümlelerini kullanır. } \\
\text { Ör. "Allaha ısmarladık.”, “Görüşürüz." }\end{array}$ \\
\hline 1.Seviye & $\begin{array}{l}\text { Tanışma ve } \\
\text { Arkadaşlık }\end{array}$ & $\begin{array}{l}\text { 2.1.3.Duruma göre özür ve nezaket cümleleri söyler. } \\
\text { Ör. "Tanıştığımıza memnun oldum.” }\end{array}$ \\
\hline 1.Seviye & Tanışma ve & 2.1.4. Herhangi bir arkadaşını veya kişiyi başka bir kişiyle tanıştırır. \\
\hline
\end{tabular}

\footnotetext{
Adres $\mid$ Address

İstanbul Medeniyet Üniversitesi, Eğitim Bilimleri Fakültesi, Türkçe İstanbul Medeniyet University, Faculty of Education Sciences, ve Sosyal Bilimler Eğitimi Bölümü, Türkce Eğitimi ABD Cevizli Turkish and Social Scinces Education, Turkish Language Teaching Kampüsü, Kartal-İstanbul/TÜRKIYE $\quad$ Education, Cevizli Campus, Kartal-İstanbul /TURKEY e-posta: editor@rumelide.com 1 e-mail: editor@rumelide.com
} 
Evaluation of Turkish language teaching for foreigners course programs of general directorate of lifelong learning in terms of various variables /T. Aytan; O. Uzun; Y. Günaydın ( (pp. 70-99)

\begin{tabular}{|c|c|c|}
\hline & Arkadaşlık & Ör. "Merhaba, bu Ali, bu da Mehmet" \\
\hline 1.Seviye & $\begin{array}{l}\text { Tanışma ve } \\
\text { Arkadaşlık }\end{array}$ & 2.2.2.Memleket, vatan, ülke, devlet, şehir kelimelerini öğrenir. \\
\hline 1.Seviye & $\begin{array}{l}\text { Tanışma ve } \\
\text { Arkadaşlık }\end{array}$ & $\begin{array}{l}\text { 2.2.4."Nerelisin?” soru kalıbını kullanarak kişilerin nereli olduklarını sorar. } \\
\text { Ör. "Nerelisin?”, "Kırklareliliyim”, “Nerelisin?”, “Çorumluyum”. }\end{array}$ \\
\hline 1.Seviye & $\begin{array}{l}\text { Tanışma ve } \\
\text { Arkadaşlık }\end{array}$ & $\begin{array}{l}\text { 2.2.5.Nerede yaşadığını söyler ve yazar. } \\
\text { Ör."Ben İstanbul'da yaşıyorum.”, “ Kadıköy’de yaşıyorum.”, “Ben Ordu'da } \\
\text { yaşıyorum.”,"Ben Erzurum’da yaşıyorum.” }\end{array}$ \\
\hline 1.Seviye & $\begin{array}{l}\text { Ailem ve } \\
\text { Çevrem }\end{array}$ & $\begin{array}{l}\text { 3.1.4.Aile bireyleriyle ilgili akrabalık terimlerini söyler. } \\
\text { Ör."anne”, "anneanne”, "dede”, "amca”, "baba...” }\end{array}$ \\
\hline 1.Seviye & $\begin{array}{l}\text { Ailem ve } \\
\text { Çevrem }\end{array}$ & $\begin{array}{l}\text { 3.1.5.Evdeki aile bireylerini tanır ve kim olduklarını sahiplik eklerini } \\
\text { kullanarak söyler. } \\
\text { Ör.“Bu kim ?”, "Bu annem”, "Bu dedemiz”, “Bu amcası", "Bu babaları” }\end{array}$ \\
\hline 1.Seviye & $\begin{array}{l}\text { Ailem ve } \\
\text { Çevrem }\end{array}$ & $\begin{array}{l}\text { 3.2.2.var - yok kelimelerini kullanarak çevresindeki eşyaların isimlerini } \\
\text { söyler ve yazar. } \\
\text { Ör."Sinıfta televizyon var mı ?”,"Televizyon yok.” “Odanda ne var ?”, } \\
\text { "Televizyon var.” }\end{array}$ \\
\hline 1.Seviye & $\begin{array}{l}\text { Ailem ve } \\
\text { Çevrem }\end{array}$ & $\begin{array}{l}\text { 3.2.3.Çevre ile ilgili verilen resimlerle kelimeleri eşleştirir. } \\
\text { Ör.“okul görseli - okul ?”,"sokak görseli - sokak”, “dağ görseli- dağ”, "göl } \\
\text { görseli- göl” }\end{array}$ \\
\hline 1.Seviye & $\begin{array}{l}\text { Ailem ve } \\
\text { Çevrem }\end{array}$ & $\begin{array}{l}\text { 3.2.7.Çevresindeki başlıca yerlerin isimlerini öğrenir. } \\
\text { Ör."bakkal ”,“okul” "pazar”, "otobüs durağl...” }\end{array}$ \\
\hline 1.Seviye & $\begin{array}{l}\text { Ailem ve } \\
\text { Çevrem }\end{array}$ & 3.2.8. Resimleri verilen yakın çevredeki yerlerin isimlerini söyler. \\
\hline 1.Seviye & $\begin{array}{l}\text { Temel } \\
\text { İhtiyaçlar }\end{array}$ & 6.1.2.Kahvaltılık yiyecekler ile öğün yemeklerini ayırt eder. \\
\hline 1.Seviye & $\begin{array}{l}\text { Temel } \\
\text { İhtiyaçlar }\end{array}$ & 6.1.7. Resimlerde verilen yiyeceklerin tekil ve çoğullarını söyler. \\
\hline 1.Seviye & $\begin{array}{l}\text { Temel } \\
\text { İhtiyaçlar }\end{array}$ & $\begin{array}{l}\text { 6.2.1.Günlük hayatta tükettiği içeceklerin adını söyler ve yazar. } \\
\text { Ör. "su”, "soda”, "şerbet”, "boza”, “çay”, "kahve”, “ayran” }\end{array}$ \\
\hline 1.Seviye & $\begin{array}{l}\text { Temel } \\
\text { İhtiyaçlar }\end{array}$ & 6.2.2.Soğuk ve sıcak içecekleri söyler. \\
\hline 1.Seviye & $\begin{array}{l}\text { Temel } \\
\text { İhtiyaçlar }\end{array}$ & 6.2.3.Dinlediği bir metinde geçen içecekleri ayırt ederek söyler. \\
\hline 1.Seviye & $\begin{array}{l}\text { Temel } \\
\text { İhtiyaçlar }\end{array}$ & 6.3.4.Kıyafetlerin adlarını ve renklerini söyler. \\
\hline 1.Seviye & $\begin{array}{l}\text { Temel } \\
\text { İhtiyaçlar }\end{array}$ & 6.3.5.Kıyafet görselleri ile kıyafet isimlerini eşleştirir. \\
\hline 1.Seviye & Meslekler & 7.1.1.Bir meslekle ilgili verilen görselden mesleği tanır. \\
\hline 1.Seviye & Meslekler & 7.1.2.Mesleklerle ilgili verilen görselleri meslek isimleri ile eşleştirir. \\
\hline 1.Seviye & Meslekler & $\begin{array}{l}\text { 7.1.3.Çevresinde sıkça kullanılan meslek isimlerini söyler. } \\
\text { Ör. "aşçı”, "öğretmen”, "bakkal”, “polis...” }\end{array}$ \\
\hline 1.Seviye & Meslekler & $\begin{array}{l}\text { 7.1.7.Meslek sahiplerinin ne iş yaptığını söyler. } \\
\text { Ör. “Aşçı yemek yapar.”, "Sucu su dağıtır.” }\end{array}$ \\
\hline 2.Seviye & Giriş & 1.1.Türk dilinin alfabesini bilir; sesleri doğru çıkarır. \\
\hline 2.Seviye & Giriş & 1.2.Karşısındaki ile selamlaşır ve kendini tanıtır. \\
\hline 2.Seviye & Giriş & 1.7.Günlük temel ihtiyaçlardan olan yiyecek, içecek ve kıyafetlerin isimlerin \\
\hline
\end{tabular}




\begin{tabular}{|c|c|c|}
\hline & & söyler ve yazar. \\
\hline 2.Seviye & Giriş & 1.10.Başlıca meslekleri bilir ve meslek sahiplerinin ne yaptıklarını söyler. \\
\hline 2.Seviye & Alışveriş & 2.1.1.Kâğıt ve demir paraları tanır ve değerini söyler. \\
\hline 2.Seviye & Alışveriş & 2.1.2.Kendi ülkesinin ve bulunduğu ülkenin para birimini söyler. \\
\hline 2.Seviye & Alışveriş & 2.2.1. Sebze ve meyveleri isimleriyle söyler. \\
\hline 2.Seviye & $\begin{array}{l}\text { Sağlık ve } \\
\text { Spor }\end{array}$ & $\begin{array}{l}\text { 3.1.1.Hastalık ve hastalanma ile ilgili basit kelimeleri söyler. } \\
\text { Ör. "tedavi, ilaç, muayene, teşhis, eczane, ağrı, mide bulantısı, sızı, kırık..." }\end{array}$ \\
\hline 2.Seviye & $\begin{array}{l}\text { Sağlık ve } \\
\text { Spor }\end{array}$ & $\begin{array}{l}\text { 3.1.3.Sağlık kurumu bölümleri ve çalışanlarını söyler. } \\
\text { Ör. "danışma, acil servis, poliklinik, ameliyathane, doktor, hemşire, hasta } \\
\text { bakıcı..." }\end{array}$ \\
\hline 2.Seviye & $\begin{array}{l}\text { Sağllk ve } \\
\text { Spor }\end{array}$ & 3.2.1.Farklı spor dallarının adlarını söyler. \\
\hline 2.Seviye & $\begin{array}{l}\text { Sağllk ve } \\
\text { Spor }\end{array}$ & 3.2.5.Verilen görsellerle spor çeşitlerini eşleştirir. \\
\hline 2.Seviye & $\begin{array}{l}\text { Günlük } \\
\text { Hayat ve } \\
\text { Etkinlikler }\end{array}$ & 4.2.1.Adres için gerekli olan mahalle, cadde, sokak gibi kelimeleri söyler. \\
\hline 2.Seviye & $\begin{array}{l}\text { Günlük } \\
\text { Hayat ve } \\
\text { Etkinlikler }\end{array}$ & $\begin{array}{l}\text { 4.2.2.Evinin veya okulunun adresini bilir ve söyler. Ör. "Gülen Muharrem } \\
\text { Pakoğlu Ortaokulu, Emek Mah., 8. Cadde, No: } 9 \text { Çankaya / Ankara." }\end{array}$ \\
\hline 2.Seviye & $\begin{array}{l}\text { Günlük } \\
\text { Hayat ve } \\
\text { Etkinlikler }\end{array}$ & $\begin{array}{l}\text { 4.2.3. "Așağı, yukarı, ileri, geri, sağa, sola” gibi yer yön bildiren kelimelerle bir } \\
\text { yeri tarif eder. Ör. "Parka gitmek için } 100 \text { metre ileri git, sonra sağa dön, park } \\
50 \text { metre ileride solda." }\end{array}$ \\
\hline 2.Seviye & $\begin{array}{l}\text { Günlük } \\
\text { Hayat ve } \\
\text { Etkinlikler }\end{array}$ & 4.2.4.Mektup, dilekçe gibi metinlere adresini yazar. \\
\hline 2.Seviye & $\begin{array}{l}\text { Serbest } \\
\text { Zaman } \\
\text { Etkinlikleri }\end{array}$ & 5.3.2.İyi ve kötü alışkanlıkların neler olduğunu söyler. \\
\hline 2.Seviye & $\begin{array}{l}\text { Serbest } \\
\text { Zaman } \\
\text { Etkinlikleri }\end{array}$ & 5.3.5.Başkalarının alışkanlıklarını sorar. \\
\hline 2.Seviye & $\begin{array}{l}\text { Hava } \\
\text { Durumu ve } \\
\text { İletişim }\end{array}$ & $\begin{array}{l}\text { 6.1.1.Hava durumu ve iklimle ilgili kelimeleri öğrenir. } \\
\text { Ör. "yağışlı, güneşli, rüzgârlı, sisli ”, "ilkbahar, yaz, sonbahar, kış.” }\end{array}$ \\
\hline 2.Seviye & $\begin{array}{l}\text { Kutlamalar } \\
\text { ve Tatil }\end{array}$ & $\begin{array}{l}\text { 7.1.1.Doğum günü, yllbaşı, dinî ve millî bayramlarla ilgili cümleler söyler. } \\
\text { Ör. "Bugün benim doğum günüm”, "Yarın Cumhuriyet Bayramı.", "Kurban } \\
\text { Bayramı tatil." }\end{array}$ \\
\hline 2.Seviye & $\begin{array}{l}\text { Kutlamalar } \\
\text { ve Tatil }\end{array}$ & $\begin{array}{l}\text { 7.1.2.Özel günlerde ne yapacağını söyler. } \\
\text { Ör. "Arkadaşıma doğum günü için hediye alacağım”, "Bugün bayram, erken } \\
\text { kalkın çocuklar." }\end{array}$ \\
\hline 2.Seviye & $\begin{array}{l}\text { Kutlamalar } \\
\text { ve Tatil }\end{array}$ & 7.1.3.Özel günlerle ilgili kısa bir diyalog yazar. \\
\hline 2.Seviye & $\begin{array}{l}\text { Kutlamalar } \\
\text { ve Tatil }\end{array}$ & $\begin{array}{l}\text { 7.2.1.Belli başlı kutlama kelimelerini öğrenir. } \\
\text { Ör. "Bayramın kutlu olsun”, "Bayramınızı tebrik ederim.”, “İyi ki doğdun.” }\end{array}$ \\
\hline 2.Seviye & $\begin{array}{l}\text { Kutlamalar } \\
\text { ve Tatil }\end{array}$ & 7.2.4. Bir kutlamayı telefonla nasıl yapacağını öğrenir. \\
\hline 2.Seviye & $\begin{array}{l}\text { Kutlamalar } \\
\text { ve Tatil }\end{array}$ & $\begin{array}{l}\text { 7.3.1.Tatil ve seyahatle ilgili kelimeleri öğrenir. } \\
\text { Ör. "gezi, tur, rehber, tatil, otel, gezi planı, bilet, varış, ayrılış..." }\end{array}$ \\
\hline
\end{tabular}


Evaluation of Turkish language teaching for foreigners course programs of general directorate of lifelong learning in terms of various variables /T. Aytan; O. Uzun; Y. Günaydın ( (pp. 70-99)

\begin{tabular}{|c|c|c|}
\hline 2.Seviye & $\begin{array}{l}\text { Kutlamalar } \\
\text { ve Tatil }\end{array}$ & 7.3.3.Tatille ilgili görselleri isimleriyle eşleştirir. \\
\hline 2.Seviye & $\begin{array}{l}\text { Kutlamalar } \\
\text { ve Tatil }\end{array}$ & $\begin{array}{l}\text { 7.3.7.Yönelme hâlini ve “-a/-e kadar” kalıbını doğru kullanarak basit bir tatil } \\
\text { planı yazar. } \\
\text { Ör. " Hafta sonu Marmaris’e gideceğim. Orada denize gireceğim.”, "Akşama } \\
\text { kadar plajda kalacağım.”, "Bir hafta sonra Ankara'ya döneceğim.” }\end{array}$ \\
\hline 2.Seviye & $\begin{array}{l}\text { Kutlamalar } \\
\text { ve Tatil }\end{array}$ & 7.4.1.Görsellerde gördüğü müzik aletlerini isimleriyle eşleştirir. \\
\hline 2.Seviye & $\begin{array}{l}\text { Kutlamalar } \\
\text { ve Tatil }\end{array}$ & 7.4.9.Seviyeye uygun Türkçe şarkıları söyler. \\
\hline 3.Seviye & $\begin{array}{l}\text { Hayallerim } \\
\text { ve Ben }\end{array}$ & $\begin{array}{l}\text { 2.1.1.Kısa kalıplaşmış cümlelerle kendisini tanıtır. } \\
\text { Ör. "Adım Ayşe, Gaziantepliyim, } 13 \text { yaşındayım.” }\end{array}$ \\
\hline 3.Seviye & $\begin{array}{l}\text { Medya ve } \\
\text { Kültür }\end{array}$ & 3.1.1.TV ve radyodaki kısa anonsları ve haberleri anlar. \\
\hline 3.Seviye & $\begin{array}{l}\text { Medya ve } \\
\text { Kültür }\end{array}$ & 3.1.3.TV ve radyodaki güncel konularla ilgili konuşmaları anlar. \\
\hline 3.Seviye & $\begin{array}{l}\text { Medya ve } \\
\text { Kültür }\end{array}$ & 3.2.2.Bir kültürel etkinlik davetiyesini okur ve anlar. \\
\hline 3.Seviye & $\begin{array}{l}\text { Medya ve } \\
\text { Kültür }\end{array}$ & 3.2.4.Katıldığı bir etkinliği anlatır. \\
\hline 3.Seviye & $\begin{array}{l}\text { Medya ve } \\
\text { Kültür }\end{array}$ & 3.2.6.Bir kültürel etkinlikle ilgili kısa bir diyalog yazar. \\
\hline 3.Seviye & $\begin{array}{l}\text { İş ve } \\
\text { Meslekler }\end{array}$ & 4.1.4.Eğitim veren kurumları söyler. \\
\hline 3.Seviye & $\begin{array}{l}\text { İş ve } \\
\text { Meslekler }\end{array}$ & $\begin{array}{l}\text { 4.1.5.Ĕ̆itim kurumlarında çalışan personellerin unvanlarını söyler. } \\
\text { Ör. “Ö̆ğretmen, Okul Müdürü, Müdür Yardımcısı, Rehber Öğretmen.” }\end{array}$ \\
\hline 3.Seviye & $\begin{array}{l}\text { İş ve } \\
\text { Meslekler }\end{array}$ & 4.2.1.Mesleklerin isimlerini sayar. \\
\hline 3.Seviye & $\begin{array}{l}\text { İş ve } \\
\text { Meslekler }\end{array}$ & 4.2.2. Resimleri verilen mesleklerin altına isimlerini yazar. \\
\hline 3.Seviye & $\begin{array}{l}\text { Anılar- } \\
\text { Geçmiş }\end{array}$ & $\begin{array}{l}\text { 5.2.5. Keşifler ve icatlar, önemli buluşlar ve önemli şahsiyetler hakkında } \\
\text { okuduğu bir metnin ana noktalarını anlar. }\end{array}$ \\
\hline 3.Seviye & $\begin{array}{l}\text { Toplum ve } \\
\text { Birey }\end{array}$ & $\begin{array}{l}\text { 6.1.1.İnsan ilişkileri, misafirlik, arkadaşlık, aile, akrabalık ve komşuluk } \\
\text { ilişkileri gibi konularda yapılan bir sohbeti ana hatları ile anlar. }\end{array}$ \\
\hline 3.Seviye & $\begin{array}{l}\text { Toplum ve } \\
\text { Birey }\end{array}$ & $\begin{array}{l}\text { 6.2.1. Radyo ve TV programlarında toplumsal kurallarla ilgili bir sunumu } \\
\text { anlar. } \\
\text { Ör. "görgü", "nezaket" gibi konularda. }\end{array}$ \\
\hline 3.Seviye & $\begin{array}{l}\text { Toplum ve } \\
\text { Birey }\end{array}$ & $\begin{array}{l}\text { 6.2.2.Toplumsal kurallarla ilgili önerilerde bulunur. } \\
\text { Ör. "Yaşlılara yer vermeliyiz.”, "Geç saatlerde gürültü yapmamalıyız." }\end{array}$ \\
\hline 3.Seviye & $\begin{array}{l}\text { Toplum ve } \\
\text { Birey }\end{array}$ & $\begin{array}{l}\text { 6.3.5.Yol tariflerini anlar, yapar, yol tarifini öğrenmek amaciyla yer ve yön } \\
\text { sorar. }\end{array}$ \\
\hline 3.Seviye & $\begin{array}{l}\text { Duygular ve } \\
\text { Sanat }\end{array}$ & $\begin{array}{l}\text { 7.1.4.Duygusal ifadeleri içeren kelimeler ile cümleler kurar. } \\
\text { Ör. "Çocuklar ağlayınca çok üzülürüm.”, "Türkçeyi öğrenmeye hevesliyim.”, } \\
\text { "Hayvanları incitenlere kızarım.” }\end{array}$ \\
\hline 3.Seviye & $\begin{array}{l}\text { Duygular ve } \\
\text { Sanat }\end{array}$ & $\begin{array}{l}\text { 7.2.1.Güzel sanatların neler olduğunu söyler. } \\
\text { Ör. "resim, müzik, heykeltıraşlık, mimarlık, edebiyat, musiki..." }\end{array}$ \\
\hline 3.Seviye & $\begin{array}{l}\text { Duygular ve } \\
\text { Sanat }\end{array}$ & $\begin{array}{l}\text { 7.2.2. Resim, müzik, tiyatro ve benzeri konularda konuşmalara hazırlık } \\
\text { yaparak katılır. Fikirlerini söyler, öneride bulunur. }\end{array}$ \\
\hline
\end{tabular}

Tablo. 14 Kültürel Ögeler Tablosu

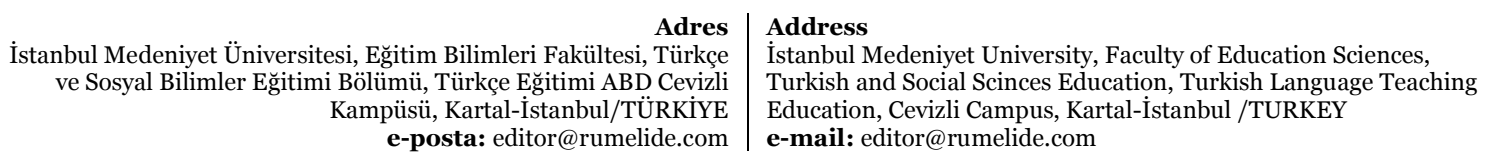


Yabancı Diller Yabancılara Türkçe Öğretimi 1, 2 ve 3. Seviye Kurs Programında yer alan konu başlıkları ve kazanımlar incelendiğinde, Türk kültürüne ait ögeleri barındıran ve söz konusu kültürel ögeleri yabancı dil olarak Türkçeyi öğrenen bireylere aktarabilecek kapasitede olan kazanımların listesi yukarıdaki tabloda yer almaktadır. Söz konusu tabloda 1, 2 ve 3. seviyeden kazanımlar bulunmaktadır.

\section{Sonuç, tartışma ve öneriler}

Türkçenin yabancı dil olarak öğretimi hem dil becerileri hem de kültür aktarımı bakımından büyük önem taşıyan bir süreçtir. Birey, yabancı bir dile hâkim olabilmek ve o dilin konuşucularıyla sağlıklı bir iletişim kurabilmek için dil becerilerini, özellikle konuşma ve dinleme becerisini kurallarına uygun biçimde kullanabilmelidir. "Konuşur, yazar, dinleyici ya da okuyucu olarak etkinlikte bulunmak için dil öğrenenlerin bir dizi eylemin uygulanmasına ilişkin deneyim sahibi olmaları gerekir”(CEFR,2001). Söz konusu bir dizi eylem şu şekilde belirtilmektedir:

Konuşabilmek için dil öğrenenlerin iletiyi planlayıp düzenlemesi, dilsel anlatımı ifade edebilmesi, ifadeyi telaffuz edebilmesi gerekmektedir. Yazabilmek için öğrenenlerin mesajı düzenlemesi, ifade edebilmesi, el yazısı ya da klavye kullanarak iletiyi yazıya dökmesi gerekmektedir. Dinleyebilmek için dil öğrenenlerin anlatımı algılamaları, dilsel iletiyi tanıyabilmeleri, iletiyi anlayabilmeleri, iletiyi yorumlayabilmeleri gerekmektedir. Okuyabilmek için ise yazılı metni algılayabilmeleri, yazıyı tanıyabilmeleri, iletiyi tanıyabilmeleri, iletiyi anlayabilmeleri ve iletiyi yorumlayabilmeleri gerekmektedir.

Yabancı dil öğreniminde dil becerileri öğretiminin yanında hedef dilin sahip olduğu kültürel hazinenin de farkında olunması gerekmektedir. Kültür, kapsamı itibarıyla dilden ayrı yorumlanamaz bir kavramdır, "belirli bir topluluğa ait sosyal davranışlar ve teknik kuruluşlar" (Kafesoğlu, 2019) anlamına gelmektedir. "Sosyal davranışlar" ile ifade edilmek istenen, toplumun birbirleriyle ve başka toplumlarla olan ilişkileridir. Bu noktada kültür için ön planda olan kavram dildir. Dil, kültürü taşır; kültür ise dili besler. Bir dili öğrenmek aynı zamanda o dilin taşıyıcısı olduğu kültürü de öğrenmek anlamina gelir (Kramsch, 1993).

Yabancı dil öğrenicisinin, dört temel dil becerisini aktif olarak kullanabilmesi ve hedef dilin doğal konuşucularıyla akıcı bir biçimde konuşabilmesi için o dile ait temel kültürel kavramları ve bu kavramların hangi bağlamda nasıl kullanıldığını da bilmesi gerekmektedir. Aksi durumda dört temel dil becerisinin kullanımı mekanik bir kullanımdan öteye geçemeyebilir; birey, hedef dilin doğal konuşucularıyla sağlıklı bir iletişim kuramayabilir. Diller İçin Avrupa Ortak Başvuru Metni (2001) `ne göre dil öğreniminin üst seviyede gerçekleşebilmesi için dil öğrenenlerin gereksinimlerinin göz önünde bulundurulmasının yanında, öğrenilen dilin kültürel çerçevesinin iyi bir şekilde belirlenerek programın oluşturulması da gerekmektedir.

Bu noktadan hareketle Hayat Boyu Öğrenme Genel Müdürlüğü tarafından Diller için Avrupa Ortak Başvuru Metni (CEFR, 2001) temel alınarak hazırlanan Yabancı Diller Yabancılara Türkçe Öğretimi 1, 2 ve 3. Seviye Kurs Programları dil becerileri ve kültür ögeleri bakımından ele alınarak incelenmiştir.

Araştırmanın birinci alt problemi "Programda yer alan kazanımların dil becerilerine göre dağılımı nasıldır?” doğrultusunda her seviyenin birinci, dördüncü ve yedinci konularında yer alan kazanımlar beceri dağılımı açısından incelenerek bulgular bölümünde sunulmuştur. Bu bölümde elde edilen

Adres

İstanbul Medeniyet Üniversitesi, Eğitim Bilimleri Fakültesi, Türkce ve Sosyal Bilimler Eğitimi Bölümü, Türkce Eğitimi ABD Cevizli Kampüsü, Kartal-İstanbul/TÜRKIYE e-posta: editor@rumelide.com 
Evaluation of Turkish language teaching for foreigners course programs of general directorate of lifelong learning in terms of various variables /T. Aytan; O. Uzun; Y. Günaydın ( (pp. 70-99)

verilere göre, söz konusu programda "konuşma” ve “dil bilgisi” becerilerinin ağırlıkta olduğu tespit edilmiştir.

Dilin kurallarının kavratılması için gerekli olan dil bilgisi eğitimi ile o dilin doğru konuşulabilmesi, hedef dili anadili olarak kullananlar kadar vurgu, ton, durak vb. seslendirme biçimlerini düzgün ve doğru biçimde yapması gerekmektedir (Benhür, 2002:100). Bununla beraber konuşma becerisi, bireyin günlük yaşantısı başta olmak üzere hayatının her alanında diğer dil becerilerine göre daha sik kullanmaktadır (Demirel, 1999). Aynı zamanda konuşma becerisi yabancı dil öğrenim sürecinde en çok sorun yaşanan alan olarak belirtilmektedir (Ladousse, 2002). Bu nedenle programda konuşma ve dil bilgisi becerilerine daha fazla ağırlık verildiği söylenebilir.

İlgili kazanımlar içerisinde yer alan ifadeler öz konusu kazanımların hangi beceri alanına ait olduğu konusunda genellikle ipucu vermektedir. "Söyler, kullanır, yazar, sayar" gibi ifadeler, kazanımın konuşma ya da yazma becerisine yönelik olduğunu göstermektedir. Bununla beraber "öğrenir, dikkat eder, bilir, tanır" gibi ifadeler ise ilgili kazanımın okuma, dinleme ya da dil bilgisi becerisine yönelik olduğunu göstermektedir. "5.1.1. Hobi ve fobi kelimelerinin anlamını öğrenir", "hobiler ve fobilerle ilgili basit bir metni anlayarak okur” kazanımları örnek olarak gösterilebilir.

Programda görsel okuma alanına giren kazanımlar bulunmaktadır. Sever (2007: 18) `e göre görsel unsurlar, nesne ya da varlıkların görsel benliklerinin farkında olma, isimlendirme ve hafızada zamanı geldiğinde kullanmak için depolama gibi bilişsel süreçlerin harekete geçmesini sağlar. Arslan ve Gürdal (2012) tarafından gerçekleştirilen bir çalışmada, yabancılara Türkçe kelime öğretirken çeşitli görseller kullanılmasının kelimenin doğru ve kolay kavranmasını sağlayıp çabuk unutulmasını engellediği belirtilmektedir. Saat, Er ve Üstten (2018) tarafından gerçekleştirilen bir çalışmada, görsel araçların yabancı dil öğretimine etkisi ele alınmıştır. Araştırma sonucunda, görsel araçlardan biri olan karikatürün desteğiyle sürdürülen derslerin öğrenciyi isteklilik, anlaşılırlık, kalıcılık ve üretkenlik gibi birçok özellik sayesinde başarıya ulaştırdığı tespit edilmiştir.

Araştırmada ele alınan programlarda var olan görsel okuma ile ilişkili olan kazanımlardan bir kısmı şunlardır: "7.1.1. Bir meslekle ilgili verilen görselden mesleği tanır", "7.3.3. Tatille ilgili görselleri isimleriyle eşleştirir", "görsellerde gördüğü müzik aletlerini isimleriyle eşleştirir”, "7.1.2. görsellerde verilen duyguların adlarını söyler". Bireyin sadece metinden hareketle okuma ve okuduğunu cevaplama çalışmaları yapması yerine görseller de işin içine katılarak anlamayı artırıcı çalışmalara yer veren kazanımlar bulunmaktadır. Ancak söz konusu kazanımlar, programın geneli itibarıyla yer alan toplam kazanım sayısı içerisinde çok az yer tutmaktadır. Böyle bir durumda, dil öğretim programı başta olmak üzere yabancı dil olarak Türkçe öğretimi alanında kullanılan materyallerin görsel okumayı destekleyici şekilde hazırlanması oldukça önemlidir.

Ana dilinde olduğu kadar yabancı dil olarak Türkçe öğretiminde de kültürel ögelere vurgu yapmak oldukça önemlidir. Çünkü bir dili öğretmek sadece o dile ait kuralları öğretmek anlamına gelmemektedir. Hedef dilde konuşulanları anlayabilmek ve o dilde düşünüp konuşabilmek için dilin soyut alanına hâkim olmak gerekmektedir. Bunun için dilin yansıtıcısı olan kültürü ve kültüre ait ögeleri öğrenmek önemlidir. "Bu sayede hedef dili öğrenen birey o dildeki inceliklere hâkim olup o dilde düşünmeye başlayacaktır” (Kutlu,2014). Böyle bir durumda, kültürel ögelerin hangilerinin öğretileceği, üzerinde durulması gereken önemli bir konudur. "Günlük hayat kullanımları başta olmak üzere ilgi çekici ve hedef dilin konuşucularıyla ortak bir alan oluşturacak konulara yer verilmesi gerekmektedir" (Vargelen, 2013).

Adres 
Araştırmanın ikinci alt problemi "1.Yabancı Diller Yabancılara Türkçe Öğretimi 1, 2 ve 3. Seviye Kurs Programının Türk kültürüne ait ögeleri yansıtma durumu nasıldır?” doğrultusunda elde edilen bulgular incelendiğinde, birinci seviye kurs programında "Tanışma ve Arkadaşlık", "Ailem ve Çevrem”, "Temel İhtiyaçlar”, "Meslekler” gibi günlük hayat ile ilişkili konu başlıkları altında söz konusu kültürel ögeleri yansıtma gücünü barındıran kazanımlar yer almaktadır.

Örneğin, “6.2.3. Dinlediği bir metinde geçen içecekleri ayırt ederek söyler” kazanımı Türk kültüründe bulunan içecekleri yansıtacak şekilde hazırlanacak bir etkinlikle sunulduğunda, söz konusu potansiyel kullanılmış olacaktır. Bir diğer örnekte, "3.1.3. Evdeki aile bireylerini tanır ve kim olduklarını sahiplik eki kullanarak söyler” kazanımı Türk aile yapısını etkinlikler aracılığıyla dil öğrenicilerine sunmak için uygundur.

Birinci seviye kurs programında, Türk kültürünü yansıtma potansiyeline sahip yirmi dört kazanım bulunmaktadır. İkinci seviye kurs programında ise "Giriş" başlı̆̆ı altında bir önceki seviyeyi geçen öğrencinin durumunu tespit etmek amacıyla sunulan kazanımlarla birlikte seviye genelinde Türk kültürünü yansıtma potansiyeline sahip yirmi sekiz kazanım bulunmaktadır. "7.1.1. Doğum günü, yılbaşı, dinî ve millî bayramlarla ilgili cümleler söyler” kazanımı, Türk kültüründe var olan bayramların öğrencilere aktarılması açısından kullanılabilir durumdadır. "Alışveriş, Sağlık ve Spor, Günlük Hayat ve Etkinlikler, Serbest Zaman Etkinlikleri, Hava Durumu ve İletişim, Kutlamalar ve Tatil” başlıkları altında da Türk kültürünü aktarma gücüne sahip kazanımlar bulunmaktadır. Kutlamalar ve Tatil başlığı altında bulunan "7.4.1. Görsellerde gördüğ̈̈ müzik aletlerini isimleriyle eşleştirir” kazanımını ele aldığımızda, öğrenciye Türk kültüründe var olan ve sıklıkla kullanılan müzik aletlerinin neler olduğu öğretilerek müzikal anlamda bir kültür bilinci oluşturulabilir. "7.4.9. Seviyeye uygun Türkçe şarkılar söyler” kazanımı ele alındığında da dil öğrenicisine Türk kültürünün geniş sanat hazinesinden seviyeye uygun şarkılar seçilerek bu şarkılar öğretilebilir.

Programın son seviyesi olan üçüncü aşamada ise Türk kültürüne ait ögeleri yansitacağı düşünülen on sekiz kazanım tespit edilmiştir. Son seviyede daha çok kazanımın bulunması beklenirken tespit edilen kazanımların azlığı dikkat çekmektedir. Söz konusu kazanımlar, "Hayallerim ve Ben, Medya ve Kültür, İş ve Meslekler, Anılar ve Geçmiş, Birey ve Toplum, Duygular ve Sanat” başlıklarına sahip konular altında sıralanmaktadır. "5.2.5. Keşifler, icatlar, önemli buluşlar ve önemli şahsiyetler hakkında okuduğu bir metnin ana noktalarını anlar" kazanımında, Türk tarihinde önemli işlere imza atmış bilim adamları, Türk bilim tarihi gibi birçok konuda etkinlik hazırlanarak öğrencilerin Türk bilim tarihinden haberdar olmaları sağlanabilir.

\section{Kaynakça}

Akcaoğlu, C. (2019). Kültürel aktarım aracı olarak somut olmayan kültürel miras. Yabancı Dil Olarak Türkçe Öğretimi Doktora Programı 1. Öğrenci Sempozyumu.

Arslan, M., Gürdal, A. (2012). Yabancılara Görsel Ve İşitsel Araçlarla Türkçe Kelime Öğretim Yöntemi, Kastamonu Eğitim Dergisi. Cilt: 20, No: 1, S.255-270.

Banguoglu, T. (1986). Türkçenin grameri. Türk tarih kurumu.

Barın, E. (2004). Yabancılara Türkçe Öğretiminde İlkeler. Hacettepe Üniversitesi Türkiyat Araştırmaları (HÜTAD), (1), 19-30.

Bayraktar, N. (2003). Yabancılara Türkçe Öğretiminin Tarihsel Gelişimi. Dil Dergisi, (119), 58-71.

Benhür M H (2002) Türkçenin yabancılara öğretiminde tartışılmayan ana kavramlar. Yayımlanmamış doktora tezi. Ankara: Gazi Üniversitesi.

\footnotetext{
Adres $\mid$ Address

İstanbul Medeniyet Üniversitesi, Eğitim Bilimleri Fakültesi, Türkçe İstanbul Medeniyet University, Faculty of Education Sciences, ve Sosyal Bilimler Eğitimi Bölümü, Türkçe Eğitimi ABD Cevizli $\quad$ Turkish and Social Scinces Education, Turkish Language Teaching Kampüsü, Kartal-İstanbul/TÜRKIYE $\quad$ Education, Cevizli Campus, Kartal-İstanbul /TURKEY

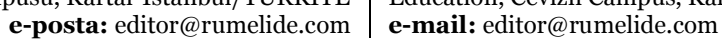


Evaluation of Turkish language teaching for foreigners course programs of general directorate of lifelong learning in terms of various variables /T. Aytan; O. Uzun; Y. Günaydın ( (pp. 70-99)

Caner, M., Direkçi, B., Kurt, B.(2019). Yabancı Dil Olarak Türkçe Öğretiminde Kültür Aktarımına İlişkin Öğretmen Adaylarının Görüşleri. Dil Eğitimi ve Araştırmaları Dergisi 5(2), 76-92.

Common European Framework of Reference for Languages learning, teaching, assessment. (2001). Cambridge: Cambridge University Press.

Çelik, H. (2018). Yabancı Dil Olarak Türkçe Öğretiminde Kültürel İhtiyaç Analizi. Hacettepe Üniversitesi, Türkiyat Araştırmaları Enstitüsü Türkiyat Araştırmaları Anabilim Dalı Yabancı Dil Olarak Türkçe Öğretimi Doktora Programı, Doktora Tezi.

Çiftçi, E. (2019). Türkçenin İkinci Dil Olarak Öğretiminde Kullanılan "Yabancı Uyruklu Öğrenciler için Türkçe” Kitabında Kültür Aktarımı. XI. Uluslararası Dünya Dili Sempozyumu, 16-18 Ekim 2019, Samsun.

Demirel Ö (1999) İlköğretim Okullarında Türkçe Öğretimi (MEB)

Demirel, Ö. (2011). Öğretim İlke Ve Yöntemleri: Öğretme Sanatı. Pegem Akademi.

Demirkan, M., Başkan, N. S. (2016). Türkçenin Entegrasyon Dili Olarak Öğretilmesine Dair Bulgular. Yabancılara Türkçe Öğretimi Üzerine Araştırmalar Sempozyumu, 20-21.

Dilaçar, A. (1968). Dil, diller ve dilcilik. Türk Tarih Kurumu.

Dursun, B.(2017). Yabancılara Türkçe Öğretiminde Film Kullanımının Öğrencilerin Anlama Becerisine Etkisi. Gaziosmanpaşa Üniversitesi. Yüksek Lisans Tezi.

Elbir, B., Aka, N., F. (2015). Yabancılara Türkçe Öğretiminde Kültür Aktarımına Yönelik Yapılan Çalışmaların Değerlendirilmesi. Turkish Studies, 10(12), 371-386.

Ergin, M. (2000). Edebiyat ve Eğitim Fakültelerinin Türk Dili ve Edebiyatı Bölümleri İçin Türk Dil Bilgisi. İstanbul: Bayrak.

Gökalp, Z. (1975). Türkçülüğün Esasları, İstanbul: Sebil Matbaacılık.

Güvenç, B. (1974). İnsan ve Kültür. Ankara: Elips Kitap.

Hasırcı, S. (2019). Yabancılara Türkçe Öğretimine Yönelik Ders Kitaplarındaki Konuşma Etkinliklerinin Dil Öğrenme Stratejileri Açısından İncelenmesi. Dil Eğitimi ve Araştırmaları Dergisi, 5(2), 314-333.

Hengirmen, M. (1993). Türkçenin Yabancı Dil Olarak Öğretimi. Dil Dergisi, 10, 5-9.

Türkiye `ye Giriş Yapan Yabancı ve Vatandaşlar http://www.tuik.gov.tr/PreIstatistikTablo.do?istab_id=320 (01.09.2020 tarihinde erişildi.)

İşçi, C. (2012). Türkçenin Yabancı Dil Olarak Öğgretiminde Kullanılan "Yeni Hitit” Ders Kitabının Dört Temel Dil Becerisi ve Kültür Açısından İncelenmesi. Dokuz Eylül Üniversitesi Eğitim Bilimleri Enstitüsü Yabancı Dil Olarak Türkçe Öğretimi Anabilim Dalı Yüksek Lisans Tezi.

Kafesoğlu, İ. (2019). Türk Millî Kültürü. İstanbul: Ötüken Neşriyat.

Kalenderoğlu, İ. (2015). Türkçenin Yabancı Dil Olarak Öğretiminde Kullanılan Temel Düzey (A1, A2)Ders Kitaplarında Kültür Aktarımı. 21. Yüzyılda Eğitim ve Toplum, 4(12).

Kaplan, M. (2010). Kültür ve dil (26. baskı). İstanbul: Dergâh.

Kramsch, C. (1993). Context And Culture İn Language Teaching. Oxford University Press.

Kutlu, A. (2014). Yabancıla Türkçe Öğretiminde Kültürün Araç Olarak Kullanımı: Gazi Yabancılar İçin Türkçe Öğretim Seti Örneği (B1-B2 Seviyesi). K. Ü. Kastamonu Eğitim Dergisi, 23(2), 697-710.

Ladousse G. P. (2002). Speaking Personally: quizzes and questionnaries for fluency practice (Klett Ernsth/Schullbuch).

Mattiussi, G., R. (2019). Yabancılara Türkçe Öğretiminde Dinleme Becerisinin Geliştirilmesine Yönelik Görsel-İşitsel Materyal Kullanımı Üzerine Bir Araştırma. Yıldız Teknik Üniversitesi Sosyal Bilimler Enstitüsü Türkçe Eğitimi Anabilim Dalı Türkçe Eğitimi Bilim Dalı. Yüksek Lisans Tezi.

MEB (2006). Ortaokul Türkçe Dersi Öğretim Programı ve Kılavuzu (6-8. Sinıflar).

\footnotetext{
Adres $\mid$ Address

İstanbul Medeniyet Üniversitesi, Eğitim Bilimleri Fakültesi, Türkçe ve Sosyal Bilimler Eğitimi Bölümü, Türkce Eğitimi ABD Cevizli Turkish and Social Scinces Education, Turkish Language Teaching Kampüsü, Kartal-İstanbul/TÜRKIYY $\quad$ Education, Cevizli Campus, Kartal-İstanbul /TURKEY e-posta: editor@rumelide.com 1 e-mail: editor@rumelide.com
} 
MEB (2019). Ortaokul Türkçe Dersi Öğretim Programı (İlkokul ve Ortaokul 1, 2, 3, 4, 5, 6, 7 ve 8. Siniflar).

Meriç, C.(1986). Kültürden İrfana. İstanbul: İnsan.

Mesut, G. Ü. N., Yalçın, Ç., Pişkin, B. S. (2019). Temel Seviye Yabancllara Türkçe Öğretimi Kitaplarında Yer Alan Dil Bilgisi Konularının ve Etkinliklerinin Karşılaştırılması ve Analizi. Atatürk Üniversitesi Sosyal Bilimler Enstitüsü Dergisi, 23(4), 2089-2101.

Ökten, E., C., Kavanoz, S.(2014). Yabancı Dil Olarak Türkçe Öğretimini Hedefleyen Ders Kitaplarında Kültür Aktarımı. Turkish Studies, 9 (3), 845-862.

Özdemir, C. (2013). Dil-Kültür İlişkisi: Folklor Ürünlerinin Türkçenin Yabancı Dil Olarak Öğretiminde Yeri ve İşlevi. Millî Folklor, 25 (97).

Saat, H., Er, M., Üstten, U., A. (2018). Yabancılara Türkçe Öğretiminde Karikatürün A2 Seviyesinde Dil Bilgisi Öğrenme Becerilerine Katkısı Üzerine Bir Uygulama: Hâl Ekleri Örneği. ZfWT, 10 (3), 200-217

Sever, S. (2007). “Türkçe Öğretiminde Karikatürün Kullanılması-I”. İlköğretmen Eğitimci Dergisi, 11, 18-23.

Seymen, H., Tok, M. (2015). İleri Düzey Yabancı Uyruklu Öğrencilerin Zorlandıkları Kültürel Dil Unsurlarının Tespiti ve Sınıflandırılması. Uluslararası Türkçe Edebiyat Kültür Eğitim Dergisi, 4(3), 1188-1212.

Syria Regional Refugee Response: Inter-agency Information Sharing Portal. The United Nations Refugee Agency. Erişim Adresi: http://data.unhcr.org/syrianrefugees/country.php?id=224. (13.09.2018)

Şimşek, R., \& Aktaş, T. (2016). Yabancılara Türkçe Öğretiminde Kullanılan Ders Kitaplarının Temel Dil Becerileri Bağlamında Karşılaştırmalı Olarak İncelenmesi. Yüksek Lisans Tezi. Nevşehir Hacı Bektaş Veli UUniversitesi).

Topkaya, R. (2016). Dilin Aynasında Kültür: Humboldt Felsefesinde Dil-Kültür İlişkisi. Viraverita EDergi, (4), 59-71.

Türkiye Maarif Vakfı (2019). Yabancı Dil Olarak Türkçe Dersi Öğretim Programı.

Vargelen, H. (2013). Kültürlerarası iletişimsel yeterlilik bağlamında yabancı dil olarak Türkçe öğretimi ders kitaplarının değerlendirilmesi. Yayımlanmamış Yüksek Lisans Tezi, Gazi Üniversitesi Eğitim Bilimleri Enstitüsü, Ankara.

Yabancılara Türkçe Öğretimi 1, 2 ve 3. Seviye Kur Programı (2016). Hayat Boyu Öğrenme Genel Müdürlügü̆, Millî Eğitim Bakanlığı.

Yıldırım, A., Şimşek, H. (2013). Sosyal Bilimlerde Nitel Araştırma Yöntemleri. Ankara: Seçkin.

\footnotetext{
Adres $\mid$ Address

İstanbul Medeniyet Üniversitesi, Eğitim Bilimleri Fakültesi, Türkçe İstanbul Medeniyet University, Faculty of Education Sciences,

ve Sosyal Bilimler Eğitimi Bölümü, Türkce Eğitimi ABD Cevizli Turkish and Social Scinces Education, Turkish Language Teaching

Kampüsü, Kartal-İstanbul/TÜRKIYE $\quad$ Education, Cevizli Campus, Kartal-İstanbul /TURKEY

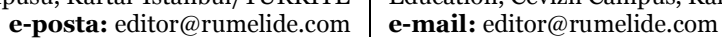

